LA-14429-PR

Progress Report

Approved for public release;

distribution is unlimited.

2009 Toxic Chemical Release Inventory

Report for the Emergency Planning and

Community Right-to-Know Act of 1986,

Title III, Section 313 
Edited by Hector Hinojosa, Group IRM-CAS.

The four most recent reports in this unclassified series are LA-14313-PR, LA-14356-PR, LA-14375-PR, and LA-14409-PR.

Los Alamos National Laboratory, an affirmative action/ equal opportunity employer, is operated by Los Alamos National Security, LLC, for the National Nuclear Security Administration of the U.S. Department of Energy under contract DE-AC52-06NA25396.

This report was prepared as an account of work sponsored by an agency of the U.S. Government. Neither Los Alamos National Security, LLC, the U.S. Government nor any agency thereof, nor any of their employees make any warranty, express or implied, or assume any legal liability or responsibility for the accuracy, completeness, or usefulness of any information, apparatus, product, or process disclosed, or represent that its use would not infringe privately owned rights. Reference herein to any specific commercial product, process, or service by trade name, trademark, manufacturer, or otherwise does not necessarily constitute or imply its endorsement, recommendation, or favoring by Los Alamos National Security, LLC, the U.S. Government, or any agency thereof. The views and opinions of authors expressed herein do not necessarily state or reflect those of Los Alamos National Security, LLC, the U.S. Government, or any agency thereof. Los Alamos National Laboratory strongly supports academic freedom and a researcher's right to publish; as an institution, however, the Laboratory does not endorse the viewpoint of a publication or guarantee its technical correctness. 
LA-14429-PR

Progress Report

Issued: October 2010

2009 Toxic Chemical Release Inventory

Report for the Emergency Planning and

Community Right-to-Know Act of 1986, Title III, Section 313

Environmental Stewardship Group (ENV-ES) 



\section{CONTENTS}

ABSTRACT. 1

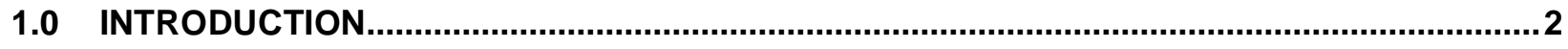

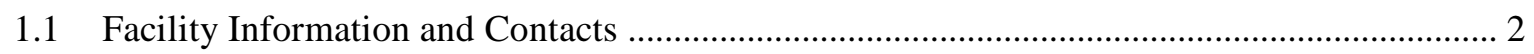

2.0 ACTIVITY DETERMINATIONS, EXEMPTIONS, AND QUALIFIERS .....................................

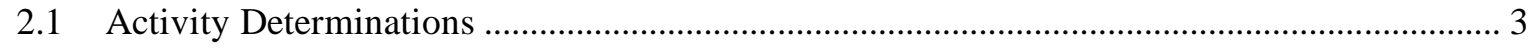

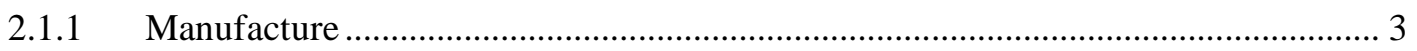

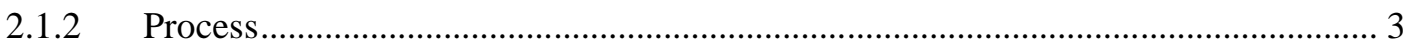

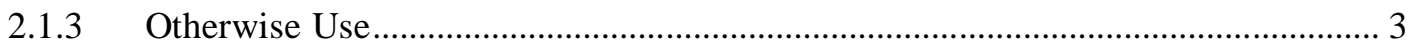

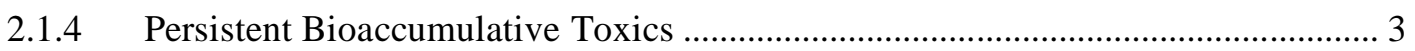

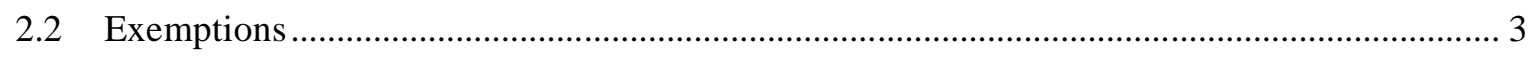

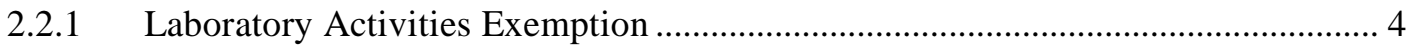

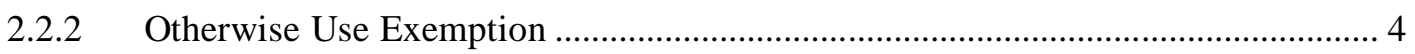

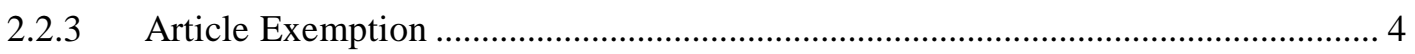

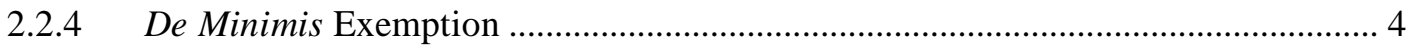

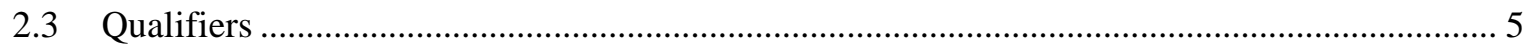

3.0 ANALYSIS FOR THRESHOLD DETERMINATIONS.......................................................

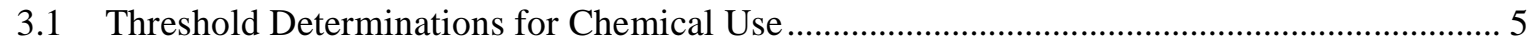

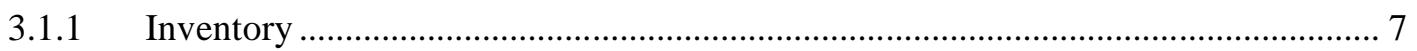

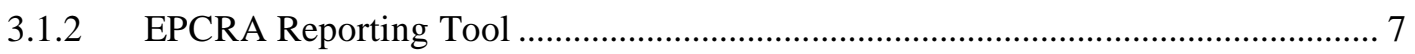

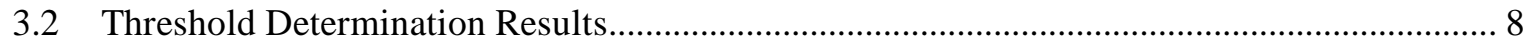

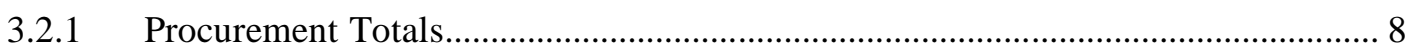

4.0 ADDITIONAL EVALUATION OF CERTAIN TOXIC CHEMICALS .......................................

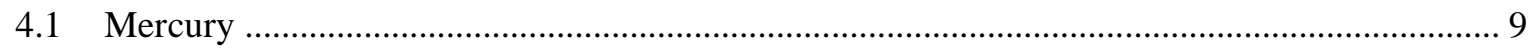

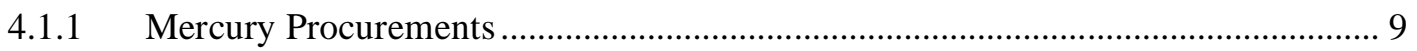

4.1.2 Los Alamos Neutron Science Center Shutter System ............................................. 9

4.1.3 Spallation Neutron Source Target Development Experiment .................................... 10

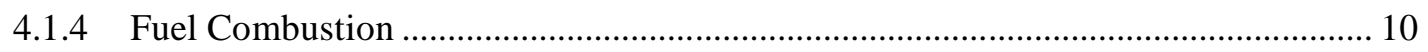

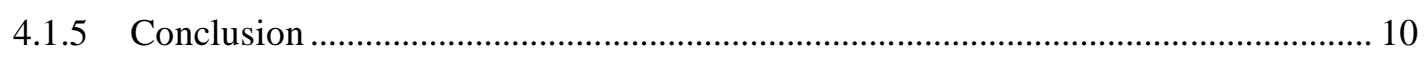

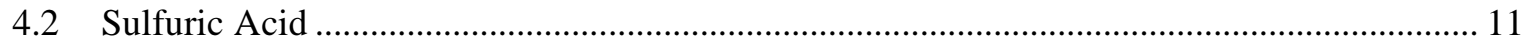

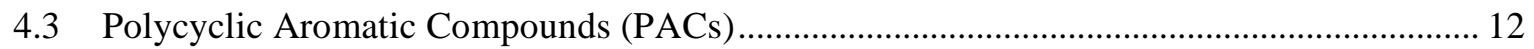

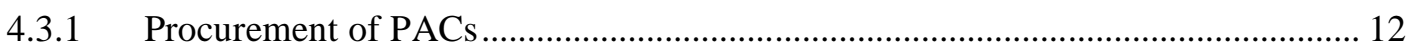

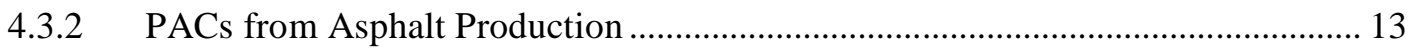

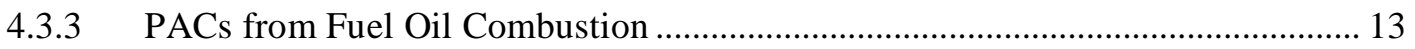

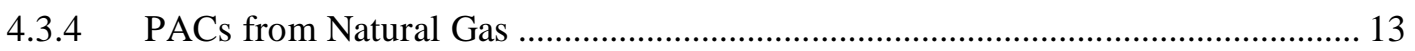

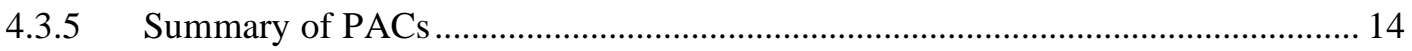

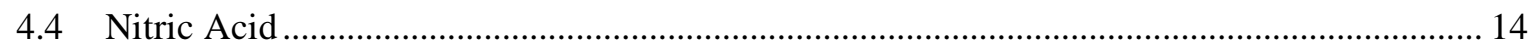

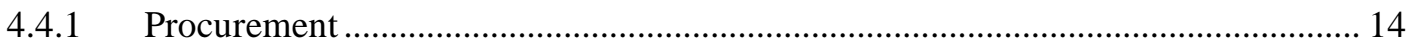

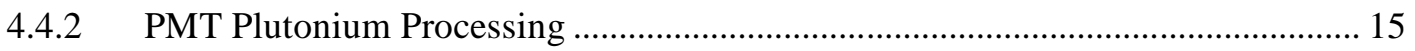

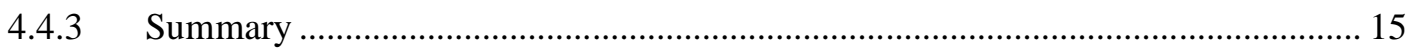

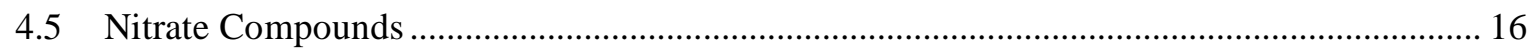




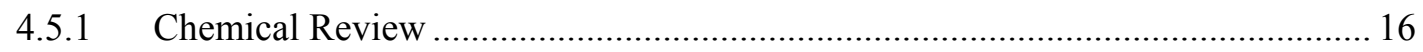

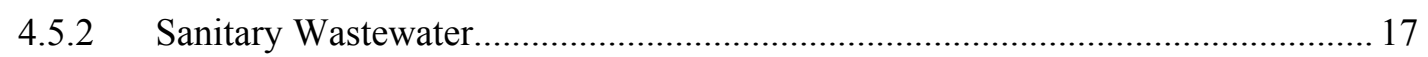

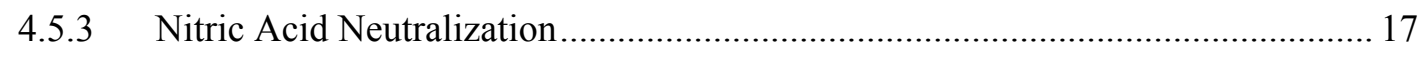

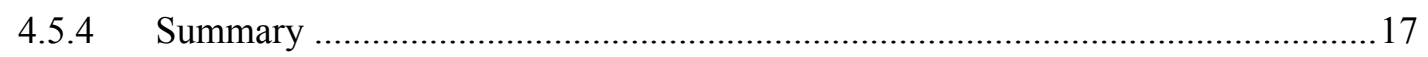

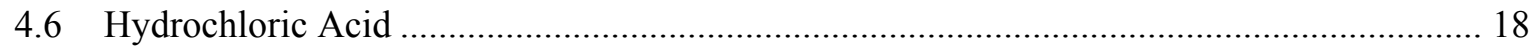

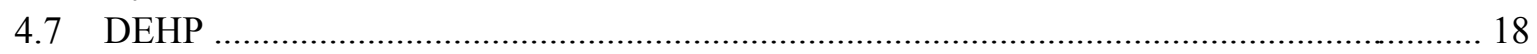

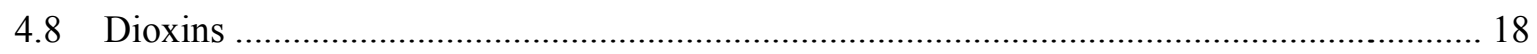

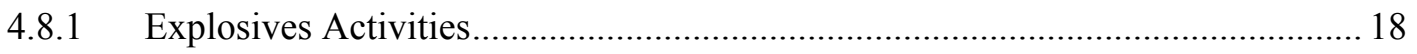

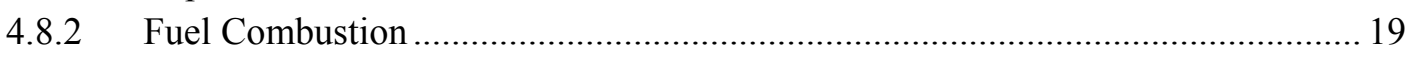

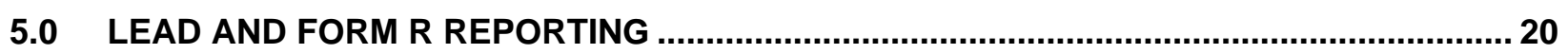

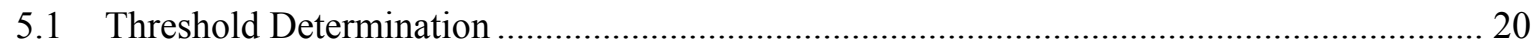

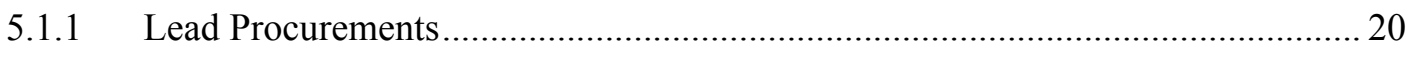

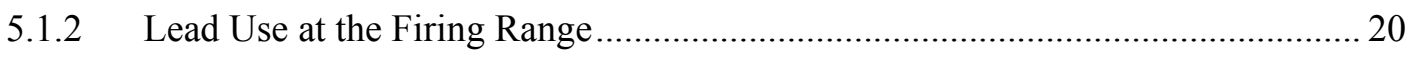

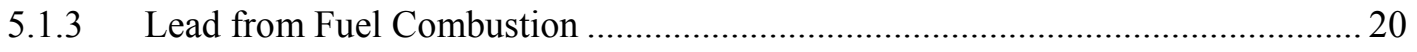

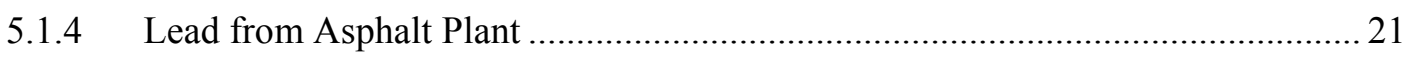

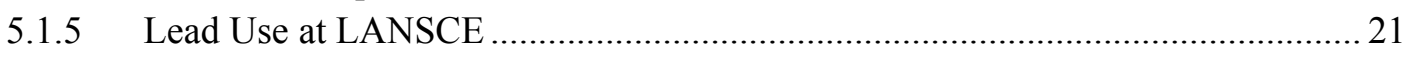

5.1.6 Other LANL Operations Using Lead and Lead Compounds ............................... 21

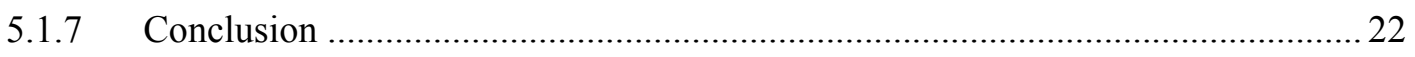

5.2 Environmental Releases and Offsite Disposal …......................................................... 22

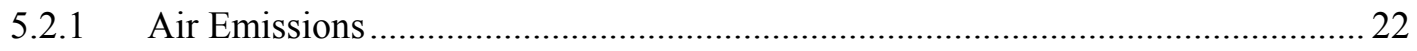

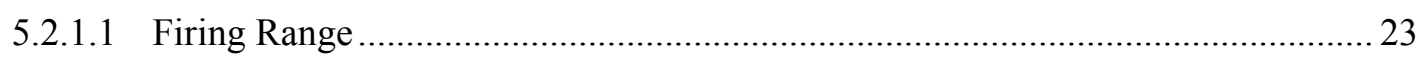

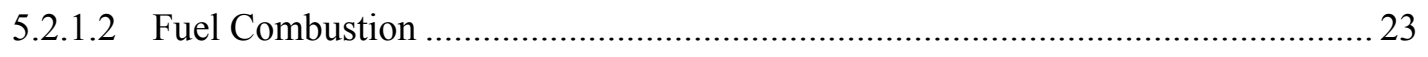

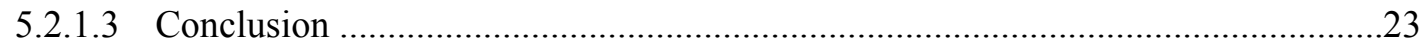

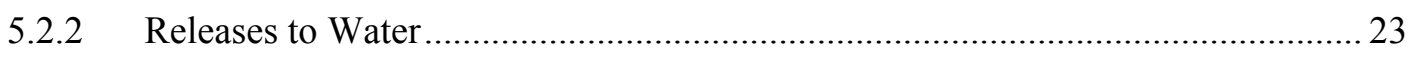

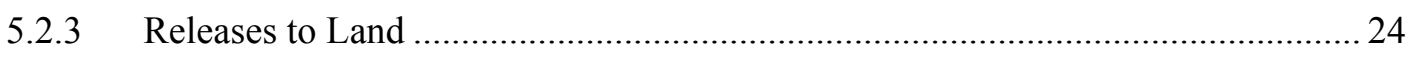

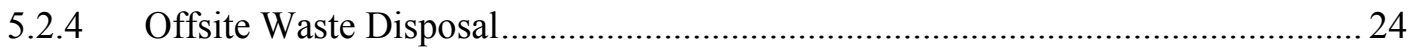

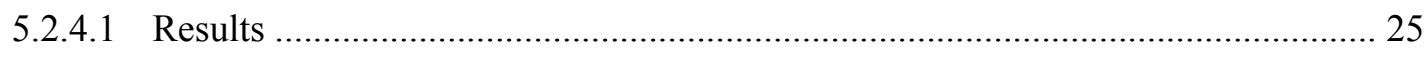

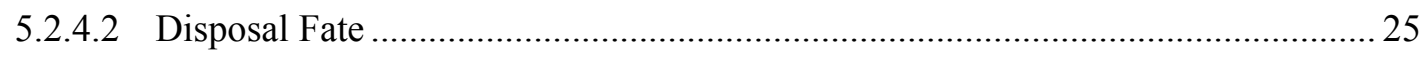

5.3 Other Information Provided on Form R Report ........................................................... 26

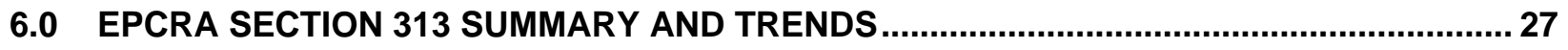

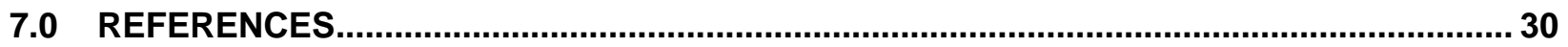

APPENDIX A: EPCRA SECTION 313 CHEMICALS USED OR PROCURED IN 2009 ................... 31

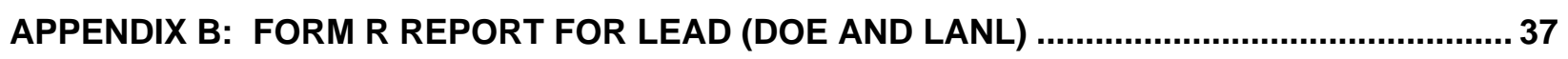




\section{Figures}

Figure 3-1 Flowchart process of analysis for EPCRA Section 313 reporting ......................................... 6

Figure 6-1 Trends in LANL's reported releases to EPA TRI.................................................................. 29

\section{Tables}

Table 2-1 Examples of EPCRA Section 313 Chemical Qualifiers ............................................................. 5

Table 3-1 Top 10 EPCRA Section 313 Chemicals Procured in 2009................................................... 8

Table 4-1 Summary of 2009 Mercury Threshold Determination........................................................... 11

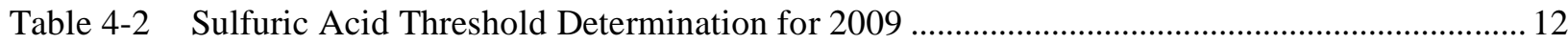

Table 4-3 LANL 2009 Threshold Determinations for PACs and Benzo(g,h,i)perylene ......................... 14

Table 4-4 Nitric Acid Threshold Determination for 2009 ........................................................................ 16

Table 4-5 Summary of Nitrate Compounds at LANL in 2009 ….......................................................... 18

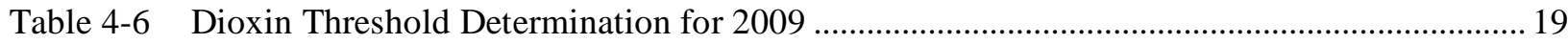

Table 5-1 Summary of Threshold Determination for Lead and Lead Compounds for 2009 .................. 22

Table 5-2 Lead Air Emissions from LANL in 2009 .............................................................................. 23

Table 5-3 Lead Releases to Water in 2009 from LANL NPDES Outfall ................................................... 24

Table 5-4 Summary of Waste Disposal Facilities Receiving LANL Waste in 2009..............................26 


\section{Acronyms and Abbreviations}

CAS Chemical Abstract Service

CFR Code of Federal Regulations

DEHP di-(2-ethylhexyl) phthalate

DOE U.S. Department of Energy

EO Executive Order

EPA U.S. Environmental Protection Agency

EPCRA Emergency Planning and Community Right-to-Know Act

$\mathrm{HCl}$ hydrochloric acid

HE high explosive

LANL Los Alamos National Laboratory

LANSCE Los Alamos Neutron Science Center

$\mathrm{lb} \quad$ pounds

$\mathrm{mg} / \mathrm{L} \quad$ milligrams per liter

MMscf million standard cubic feet

MOx mixed oxide

MRF Material Recycle Facility

MSDS material safety data sheet

NPDES National Pollutant Discharge Elimination System

OB/OD open burn/open detonation

PAC polycyclic aromatic compound

PBT persistent bioaccumulative toxic

PMT Plutonium Manufacturing and Technology (Division)

ppm parts per million

RLWTF Radioactive Liquid Waste Treatment Facility

SNS Spallation Neutron Source

$\mathrm{SO}_{3} \quad$ sulfur trioxide

SWSC Sanitary Wastewater Systems Consolidation

TA Technical Area

TRI Toxic Release Inventory

TRI-DDS TRI-Data Delivery System

WWTF Wastewater Treatment Facility

$\mu \mathrm{g} \quad$ micrograms 


\title{
2009 Toxic Chemical Release Inventory Report for the Emergency Planning and Community Right-to-Know Act of 1986, Title III, Section 313
}

by

\author{
Environmental Stewardship Group
}

\begin{abstract}
For reporting year 2009, Los Alamos National Laboratory (LANL) submitted a Form R report for lead as required under the Emergency Planning and Community Right-toKnow Act (EPCRA) Section 313. No other EPCRA Section 313 chemicals were used in 2009 above the reportable thresholds. This document was prepared to provide a description of the evaluation of EPCRA Section 313 chemical use and threshold determinations for LANL for calendar year 2009, as well as to provide background information about data included on the Form $\mathrm{R}$ reports.

Section 313 of EPCRA specifically requires facilities to submit a Toxic Chemical Release Inventory Report (Form R) to the U.S. Environmental Protection Agency (EPA) and state agencies if the owners and operators manufacture, process, or otherwise use any of the listed toxic chemicals above listed threshold quantities. EPA compiles this data in the Toxic Release Inventory database. Form R reports for each chemical over threshold quantities must be submitted on or before July 1 each year and must cover activities that occurred at the facility during the previous year.

In 1999, EPA promulgated a final rule on persistent bioaccumulative toxics (PBTs). This rule added several chemicals to the EPCRA Section 313 list of toxic chemicals and established lower reporting thresholds for these and other PBT chemicals that were already reportable. These lower thresholds became applicable in reporting year 2000. In 2001, EPA expanded the PBT rule to include a lower reporting threshold for lead and lead compounds. Facilities that manufacture, process, or otherwise use more than $100 \mathrm{lb}$ of lead or lead compounds must submit a Form R.
\end{abstract}




\subsection{INTRODUCTION}

On April 21, 2000, President Clinton signed Executive Order (EO) 13148, which requires all federal facilities to comply with the provisions of the Emergency Planning and Community Right-to-Know Act (EPCRA), or Title III of the Superfund Amendments and Reauthorization Act of 1986. EO 13148 supersedes EO 12856 of 1995. Section 313 of EPCRA specifically requires facilities to submit a Toxic Chemical Release Inventory Report (Form R) to the U.S. Environmental Protection Agency (EPA) and state agencies if the owners and operators manufacture, process, or otherwise use any of the listed toxic chemicals above listed threshold quantities. On October 19, 1999, EPA promulgated a final rule on persistent bioaccumulative toxics (PBTs). This rule added several chemicals to the EPCRA Section 313 list of toxic chemicals and established lower reporting thresholds for these and other PBT chemicals that were already reportable under EPCRA Section 313. These lower thresholds became applicable in reporting year 2000. On January 17, 2001, the PBT rule was amended to include lead and lead compounds. The rule lowered the reporting threshold for lead and lead compounds to 100 pounds (lb). The lower threshold for lead became applicable in reporting year 2001.

EPA compiles the data submitted on the Form $\mathrm{R}$ reports in a Toxic Release Inventory (TRI) database. The TRI database provides the public with information on the releases of EPCRA Section 313 chemicals in their communities as well as provides EPA with release information to assist in determining the need for future regulations (http://www.epa.gov/tri/). Form R must be submitted on or before July 1 each year and must cover activities that occurred at the facility during the previous calendar year. Even though federal facilities were not required to report under EPCRA Section 313 until 1995, Los Alamos National Laboratory (LANL or the Laboratory) had been voluntarily reporting under EPCRA Section 313 since 1987.

For reporting year 2009, the Laboratory submitted a Form R report for lead. No other EPCRA Section 313 chemicals were used in 2009 above the reportable thresholds. Toxic chemicals used in exempt activities as defined by the regulation are excluded from the threshold determinations and release calculations. Descriptions of these exempt activities are included in Section 2.2 of this report.

This report summarizes the data evaluation, exemption analysis, activity determinations, and threshold determinations for toxic chemical use at the Laboratory in 2009 and describes the environmental release data reported on the Form $\mathrm{R}$ report. Individual sections for certain toxic chemicals used at the Laboratory are included in this report. Appendix A presents a summary table of EPCRA Section 313 chemicals procured at the Laboratory in 2009. Appendix B includes a copy of the Form R report submitted to EPA and the New Mexico Environment Department.

\subsection{Facility Information and Contacts}

LANL is located at latitude of $35^{\circ} 49^{\prime} 51^{\prime \prime}$ and longitude of $106^{\circ} 14^{\prime} 15^{\prime \prime}$ in Los Alamos County, New Mexico. The Laboratory is owned by the U.S. Department of Energy (DOE) and operated by Los Alamos National Security, LLC.

Facility information is as follows:

- $\quad$ LANL

* TRI facility identification number: 87545LSLMSLOSAL

* LANL technical contact: Mr. Steve Story at (505) 665-2169 
* LANL public contact: Ms. Lorrie Bonds Lopez at (505) 667-0216

- Los Alamos DOE complex

* TRI facility identification number: 87544SDLSL52835

* DOE technical and public contact: Mr. Gene Turner at (505) 667-5794

\subsection{ACTIVITY DETERMINATIONS, EXEMPTIONS, AND QUALIFIERS}

\subsection{Activity Determinations}

EPCRA Section 313 chemical usage is evaluated against three activity determinations. For listed chemicals that are not PBTs, the thresholds are described below.

\subsubsection{Manufacture}

The term manufacture means to produce, prepare, compound, or import an EPCRA Section 313 chemical. The term manufacture also includes coincidental production of an EPCRA Section 313 chemical as a result of the manufacture, processing, otherwise use, or treatment of other chemical substances. The threshold for reporting manufactured chemicals is $25,000 \mathrm{lb}$.

\subsubsection{Process}

The term process means the preparation of a listed EPCRA Section 313 chemical, after its manufacture, for distribution in commerce. Processing is usually the intentional incorporation of an EPCRA Section 313 chemical into a product. The threshold for reporting processed chemicals is $25,000 \mathrm{lb}$.

\subsubsection{Otherwise Use}

The term otherwise use usually means any use of an EPCRA Section 313 chemical, including in a mixture or trade name product or waste that is not covered by the terms manufacture or process. The threshold for reporting otherwise use chemicals is $10,000 \mathrm{lb}$.

\subsubsection{Persistent Bioaccumulative Toxics}

For the subset of chemicals listed as PBTs, lower reporting thresholds have been established for individual chemicals ranging from $100 \mathrm{lb}$ to $0.1 \mathrm{gram}$. These lower thresholds apply to each of the activity determinations: manufacture, process, and otherwise use. Although the threshold for each activity is the same, each chemical must be evaluated against the activity determinations to determine in which activity the chemical is used. Threshold determinations for PBTs are evaluated separately against the manufacture, process, and otherwise use activities described above.

\subsection{Exemptions}

Exemptions from EPCRA Section 313 toxic chemical reporting applicable to the Laboratory are discussed below. 


\subsubsection{Laboratory Activities Exemption}

EPCRA Section 313 chemicals that are manufactured, processed, or otherwise used in laboratory activities at a covered facility under the direct supervision of a technically qualified individual do not have to be considered for threshold determinations and release calculations. However, pilot plant scale, specialty chemical production, or the use of chemicals for laboratory support activities do not qualify for this laboratory activities exemption.

\subsubsection{Otherwise Use Exemption}

Certain activities involving EPCRA Section 313 chemicals qualify as otherwise used and are specifically exempted. These include the following:

- otherwise use as a structural component of the facility,

- otherwise use in routine janitorial or facility grounds maintenance,

- personal uses by employees or other persons,

- otherwise use of products containing EPCRA Section 313 chemicals for the purpose of maintaining motor vehicles operated by the facility, or

- otherwise use of EPCRA Section 313 chemicals contained in intake water (used for processing or non-contact cooling) or in intake air (used either as compressed air or for combustion).

\subsubsection{Article Exemption}

EPCRA Section 313 chemicals contained in articles that are processed or otherwise used are exempt from threshold determinations and release calculations. For an item to be exempt as part of an article, it must satisfy the following three criteria:

- be a manufactured item that is formed to a specific shape or design during manufacture,

- have end-use functions dependent in whole or in part on its shape or design during end use, and

- must not release an EPCRA Section 313 chemical under normal circumstances of processing or otherwise use of the item at the facility. Total releases from any item or like items qualifying as article exempt must be equal to or less than $0.5 \mathrm{lb}$ to remain exempt as articles (EPA 2006).

\subsubsection{De Minimis Exemption}

The de minimis exemption allows facilities to exempt certain minimal concentrations of EPCRA Section 313 chemicals contained in mixtures or other trade name products when making threshold determinations and release calculations. The de minimis concentrations are set by EPA at either $1 \%$ or $0.1 \%$, depending on whether or not the chemical is a suspected carcinogen or carcinogen.

EPA eliminated the de minimis exemption for the list of PBT chemicals. This means that facilities must include all amounts of PBTs in threshold determinations and release and other waste management calculations regardless of the concentration of the PBTs in mixtures or trade name products. 


\subsection{Qualifiers}

In addition to exemptions, certain EPCRA Section 313 chemicals have qualifiers. Qualifiers indicate that these chemicals are subject to the reporting requirements only if manufactured, processed, or otherwise used in a specific form or when a certain activity is performed. Examples of qualifiers are shown in Table 2-1.

Table 2-1 Examples of EPCRA Section 313 Chemical Qualifiers

\begin{tabular}{lll}
\hline Chemical Name & $\begin{array}{l}\text { Chemical Abstract Service (CAS) } \\
\text { Number }\end{array}$ & Qualifier \\
\hline Aluminum & $7429-90-5$ & Only if it is a fume or dust form \\
Hydrochloric Acid $(\mathrm{HCl})$ & $7647-01-0$ & $\begin{array}{l}\text { Only if it is an aerosol form } \\
\text { Only if it is being manufactured by the strong } \\
\text { acid process }\end{array}$ \\
Isopropyl Alcohol & $67-63-0$ & Only if it is an aerosol form \\
Sulfuric Acid & $7664-93-9$ & Only when in aqueous solution \\
Nitrate Compounds & NA* & Except when contained in an alloy \\
Vanadium & $7440-62-2$ &
\end{tabular}

*NA $=$ not applicable

\subsection{ANALYSIS FOR THRESHOLD DETERMINATIONS}

There are several steps in determining when a chemical triggers reporting under EPCRA Section 313. When a chemical is manufactured, processed, or otherwise used in amounts greater than the threshold quantity, a Form R report and release calculations are required. Figure 3-1 presents a flowchart that shows the steps the Laboratory performs to determine which chemicals must be reported under EPCRA Section 313.

\subsection{Threshold Determinations for Chemical Use}

The Laboratory tracks chemicals brought onsite using a chemical inventory-tracking database called ChemLog. ChemLog captures the majority of procured chemicals and provides relevant data (e.g., chemical name, CAS number, quantity, etc.) to assist in threshold determinations. The underlying assumption used in the preliminary threshold determinations for reporting under EPCRA Section 313 is that chemicals are purchased and used in the same calendar year. If unusually large purchases are noted in this preliminary analysis, further investigation is done to determine if bulk chemicals were purchased and only a portion of them used in the calendar year. 


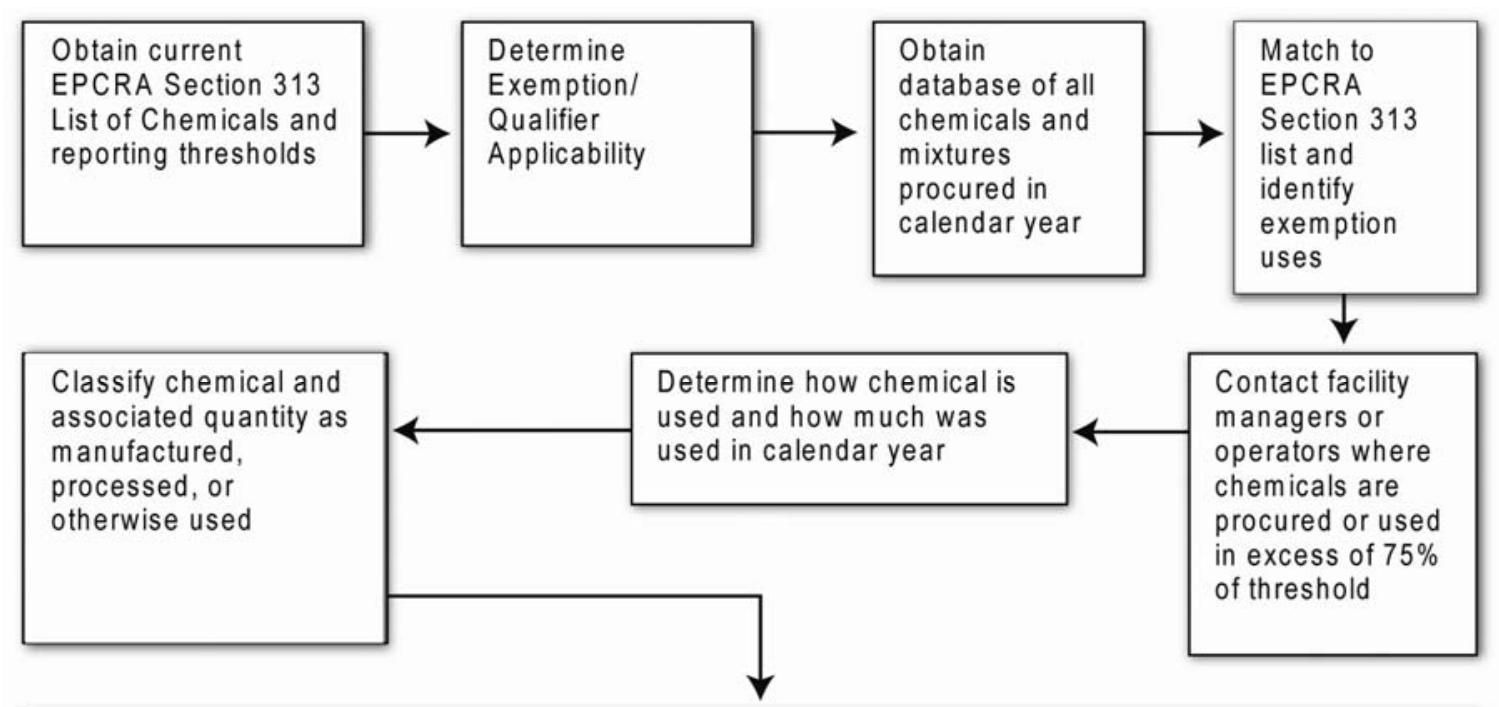

\section{DECISIONS}

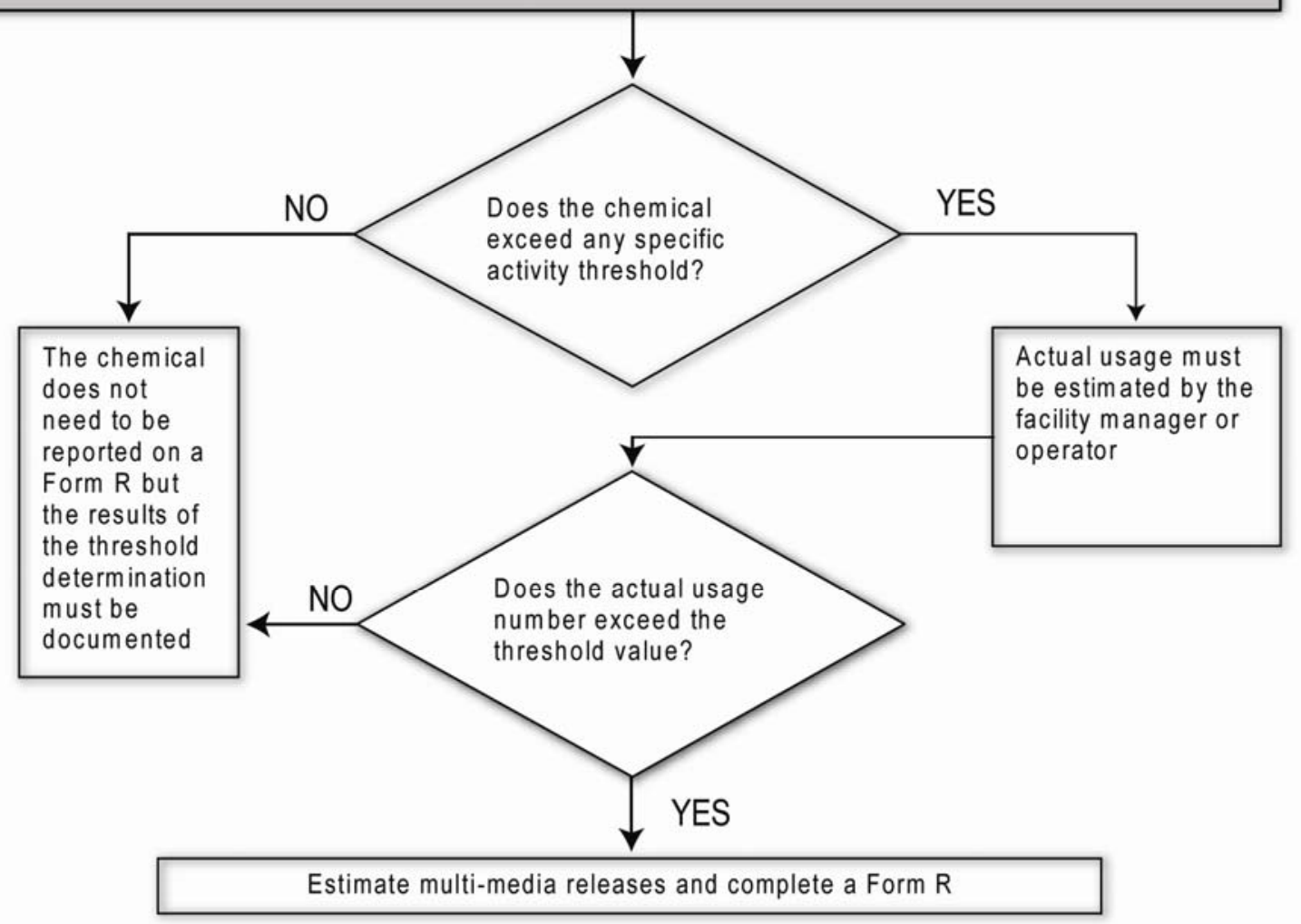

Figure 3-1 Flowchart process of analysis for EPCRA Section 313 reporting. 


\subsubsection{Inventory}

For calendar year 2009, a total of 42,244 records were added to ChemLog and evaluated; 16,728 were pure chemicals and 25,516 records were mixtures. Individual items with identifiable CAS numbers in ChemLog were considered pure chemicals. These items were matched by CAS number to the list of EPCRA Section 313 chemicals. The resulting records were summed in pounds for each pure chemical.

Individual items that did not have CAS numbers in ChemLog were considered mixtures. The exemptions discussed in Section 2.2 of this report were applied to the mixtures and each qualifying item was classified according to the applicable exemption. Material safety data sheets (MSDSs) for the remaining mixtures purchased in quantities greater than $50 \mathrm{lb}$ were reviewed to determine the presence and amount of EPCRA Section 313 constituents. This was done to ensure that the chemicals with thresholds greater than $100 \mathrm{lb}$ would be identified. Listed chemicals with thresholds less than $100 \mathrm{lb}$ were examined individually, based on process knowledge and known potential sources. Each mixture that contained an EPCRA Section 313 chemical was further evaluated to determine the weight of each constituent. The totals for these amounts were then added to the quantities of pure EPCRA Section 313 chemicals.

\subsubsection{EPCRA Reporting Tool}

An automated search tool was developed using Microsoft Access to refine the data in ChemLog. The EPCRA reporting tool performs the following steps in the ChemLog data download:

- Identifies and labels exemptions through electronic text searches. The exemptions are from 40 CFR 372.38, Exemptions for Toxic Release Reporting. When a chemical is exempt, it is not considered when determining whether an applicable threshold has been met. Specifically, chemical containers were classified as follows:

* Maintenance - routine janitorial or facility grounds maintenance (e.g., cleaning supplies, paints, fertilizers, and pesticides);

* Maintaining Motor Vehicles (e.g., antifreeze, brake fluid);

* Personal Uses - non-process-related items for employee personal use;

* De Minimus - the percent of a non-PBT Section 313 chemical in a mixture is less than $1 \%$ for a non-carcinogen or $0.1 \%$ for a carcinogen;

* Article - structural component exemption; and

* Laboratory Activities - if a toxic chemical is manufactured, processed, or otherwise used in a laboratory at a covered facility under the supervision of technically qualified individual.

- Identifies and labels EPCRA Section 313 compounds. There are 30 different chemical categories included on the EPCRA Section 313 list. Many of these categories do not have specific CAS numbers associated with them, except for polycyclic aromatic compounds (PACs) and dioxins. These two categories were evaluated in ChemLog as part of the pure chemical evaluation since they have searchable CAS numbers for compounds included in their categories. The other classes of compounds were searched in the 2009 ChemLog dataset by using chemical-specific text searches in the chemical name field.

- Matches pure chemicals (chemical containers with an identifiable CAS number) with the list of EPCRA Section 313 chemicals by matching CAS numbers. 
A few EPCRA Section 313 chemicals were selected for further analysis to determine if they were used in exempt activities. For 2009, the chemicals that were analyzed in more detail included the following:

- mercury compounds,

- $\quad$ sulfuric acid,

- PACs,

- nitric acid,

- nitrate compounds,

- $\mathrm{HCl}$,

- di-(2-ethylhexyl) phthalate (DEHP),

- dioxins, and

- lead compounds.

\subsection{Threshold Determination Results}

\subsubsection{Procurement Totals}

The amounts of listed EPCRA Section 313 chemicals identified in the ChemLog, direct procurement, and other sources were all summed together to perform preliminary threshold determinations. The resulting totals for the top 10 listed EPCRA Section 313 chemicals are summarized below in Table 3-1.

Table 3-1 Top 10 EPCRA Section 313 Chemicals Procured in 2009

\begin{tabular}{lll}
\hline CAS No & Chemical Name & Total Procured (lb) \\
\hline $7697-37-2$ & Nitric Acid & 8,534 \\
$7647-01-0$ & Hydrochloric Acid & 6,177 \\
Nitrates & Nitrate Compounds & 5,208 \\
$872-50-4$ & N-Methyl-2-pyrrolidone & 3,336 \\
$7664-93-9$ & Sulfuric Acid & 2,995 \\
Cyanide & Cyanide compounds & 2,314 \\
Polychlorinated Alkanes & Polychlorinated alkanes (C10 to C13) & 2,009 \\
$75-09-2$ & Dichloromethane & 1,928 \\
$79-01-6$ & Trichloroethylene & 847 \\
$67-56-1$ & Methanol & 687 \\
\hline
\end{tabular}

A complete table of EPCRA Section 313 chemicals showing all contributing sources is provided in Appendix A. Chemicals that were procured in amounts greater than $75 \%$ of the applicable EPCRA Section 313 threshold were evaluated further and the analyses are summarized in Section 4 of this report. 


\subsection{ADDITIONAL EVALUATION OF CERTAIN TOXIC CHEMICALS}

The toxic chemicals described below either are used in relatively high volumes at the Laboratory, have very low reporting thresholds, are of special interest, or have been reported in the past. Additional analyses were required to determine total usage of these chemicals. None of the chemicals presented in this section exceeded any of the applicable thresholds in 2009 and therefore no reporting was required.

\subsection{Mercury}

Mercury and mercury compounds are used in various places throughout the Laboratory. As part of the PBT rule, the threshold for EPCRA Section 313 reporting of mercury was reduced to $10 \mathrm{lb}$. In 2009, mercury was used in four areas at the Laboratory. Each is described below.

\subsubsection{Mercury Procurements}

A listing of all procurements in 2009 of mercury and mercury compounds was extracted from ChemLog. Line items containing a CAS number for mercury (7439-97-6) were included, as well as any line items containing the word "mercury" or the symbol "Hg" in the text description.

The total amount of mercury and mercury compounds in ChemLog for 2009 was $70.85 \mathrm{lb}$. The purchasers or users of the mercury and mercury compounds were contacted to determine the following:

- If the purchase was actually mercury or contained mercury or mercury compounds,

- If a mixture or solution, what concentration of mercury the mixture or solution contained,

- If the mercury was used in a laboratory experiment setting, if so, it is subject to the laboratory exemption under EPCRA Section 313.

According to EPCRA Section 313 guidance documents, the laboratory exemption is applied to the quantity of a listed toxic chemical that is manufactured, processed, or otherwise used in a laboratory under the supervision of a technically qualified person. A total of $10.71 \mathrm{lb}$ of mercury was determined to be laboratory exempt. Although $10.71 \mathrm{lb}$ were determined to be laboratory exempt, the actual amount of mercury in chemical containers is considerably less. The chemical names of the exempted containers are "mercury standard solutions," which contain only parts per million (ppm) quantities of mercury.

One purchase of $55.1 \mathrm{lb}$ of mercury from the Materials Technology: Metallurgy Group was investigated further. The mercury was not used in 2009 and is still in storage. Since the mercury will be used next year it will be tracked for reporting in 2010 . The mercury will be used for electroplating operations. The remaining $5.1 \mathrm{lb}$ of mercury from the ChemLog analysis were assumed to be otherwise used and applied to the $10 \mathrm{lb}$ threshold.

\subsubsection{Los Alamos Neutron Science Center Shutter System}

The largest use of mercury at the Laboratory is in the Los Alamos Neutron Science Center (LANSCE) shutter system. Reservoirs of mercury are used as shields on the neutron beam shutter system. When the beam is operated, pressurized helium is forced into the mercury reservoir, pushing the mercury up into a headspace and allowing the neutron beam to pass through the shutter. LANSCE maintains 12 neutron beam shutter systems, each with a reservoir of mercury. The total amount of mercury in these reservoirs is approximately 12,000 lb. Each reservoir is a closed system and only opened occasionally when minor repairs or maintenance are completed. 
During 2009, minor maintenance was performed on the mercury shutter system but did not involve removing or adding any mercury from the system.

\subsubsection{Spallation Neutron Source Target Development Experiment}

The Spallation Neutron Source (SNS) Target Development Experiment began operations at the Laboratory in December 2001. The experiment also operated in 2002, 2005, 2006, and 2008. The experiment studies issues associated with using mercury as the target material for the SNS. The loop is a closed system and it is not opened to the atmosphere. Additionally, the entire experiment is contained within a secondary container that includes an exhaust system that filters mercury vapor from inside the secondary container that might escape the primary mercury boundary. The exhaust system also ensures a negative pressure inside the compartment and is activated whenever the secondary compartment is opened to prevent possible mercury vapor emissions. The filtering system includes mercury and highefficiency particulate air filters.

The mercury added to the system has always been considered laboratory exempt. We assume that any mercury air emissions generated during the experiment are captured with the filtering system and therefore, no mercury air emissions are released during the experiment. LANSCE personnel confirmed that the experiment did not operate in 2009.

\subsubsection{Fuel Combustion}

In 2009, the Laboratory generated mercury compound emissions from the following combustion sources: the asphalt plant, the Technical Area (TA) 3 power plant, the TA-3 combustion turbine, and numerous small boilers. The mercury compound emissions from these sources totaled $0.36 \mathrm{lb}$ towards the manufactured threshold. Additionally, mercury is found in diesel fuel as an impurity. According to EPA guidance, the concentration of mercury in diesel fuel is $0.001 \mathrm{ppm}$ (EPA 2001a). LANL used approximately 36,230 gallons of diesel fuel in 2009 and this equates to $0.0003 \mathrm{lb}$ of mercury towards the otherwise use threshold.

\subsubsection{Conclusion}

The total amount of mercury qualifying as otherwise used equals $5.1 \mathrm{lb}$, which is below the reporting threshold value of $10 \mathrm{lb}$. The total amount of mercury compounds manufactured was $0.36 \mathrm{lb}$ and is also below the reporting threshold of $10 \mathrm{lb}$. Therefore, it was determined that reporting of mercury under EPCRA Section 313 is not necessary for 2009. A summary of the 2009 mercury threshold determination is provided in Table 4-1. 
Table 4-1 Summary of 2009 Mercury Threshold Determination

\begin{tabular}{|c|c|c|c|c|}
\hline Description & $\begin{array}{l}\text { Amount of } \\
\text { Mercury (lb) }\end{array}$ & Data Source & $\begin{array}{l}\text { EPCRA Section } 313 \\
\text { Activity Determination }\end{array}$ & $\begin{array}{l}\text { EPCRA Section } 313 \\
\text { Activity Threshold (lb) }\end{array}$ \\
\hline $\begin{array}{l}\text { Purchasing of } \\
\text { Mercury Standards } \\
\text { and Instruments }\end{array}$ & 10.7 & $\begin{array}{l}\text { Procurement data and facility } \\
\text { personnel interviews }\end{array}$ & Laboratory Exempt & NA \\
\hline Other Procurement & 55.1 & Procurement Records & Not used in 2009 & NA \\
\hline Other Procurement & 5.1 & Procurement Records & Otherwise Used & 10 \\
\hline $\begin{array}{l}\text { LANSCE Shutter } \\
\text { System }\end{array}$ & 0 & LANSCE Facility Records & & \\
\hline Fuel Combustion & 0.0003 & $\begin{array}{l}\text { Fuel Use Records and EPA } \\
\text { Guidance }\end{array}$ & Manufactured & \\
\hline Fuel Combustion & 0.36 & $\begin{array}{l}\text { Fuel Use Records and EPA } \\
\text { AP-42 }\end{array}$ & Manufactured & 10 \\
\hline
\end{tabular}

\subsection{Sulfuric Acid}

EPCRA Section 313 reporting guidelines state that sulfuric acid must be reported only if it is in aerosol form, including mists, vapors, gas, fog, and other airborne forms of any particle size. This category would include acid aerosols generated in storage tanks and from fuel combustion.

Sulfuric acid is used in liquid form for demineralizer regeneration and for sample analysis at the TA-46 Sanitary Wastewater Systems Consolidation (SWSC) Plant. In 2009, only 73 lb were used.

Sulfuric acid is also purchased in large quantities for demineralizer regeneration at TA-3-22. In 2009, $2,859 \mathrm{lb}$ of sulfuric acid were used at TA-3-22. Because the sulfuric acid used at the SWSC Plant and TA3-22 is in liquid form, it is not subject to EPCRA Section 313 reporting. TA-3-22 stores sulfuric acid in a 4,500-gallon tank. The EPA Tanks 4.0 model was used to make a very conservative estimate that 0.003 $\mathrm{lb}$ of sulfuric acid mist was generated inside the tank at TA-3-22.

Sulfuric acid aerosols are generated as a result of storage tank emissions, fuel combustion byproducts, natural gas combustion, and asphalt production. The total amount of sulfuric acid mist generated from these activities was $618.4 \mathrm{lb}$, less than the 25,000-lb manufacture threshold and, therefore, not reportable under EPCRA. Based on EPA guidance for fuel oil (diesel fuel) combustion, it is assumed that all sulfur trioxide $\left(\mathrm{SO}_{3}\right)$ emissions are in the form of sulfuric acid (EPA 1998a). For natural gas combustion, it is conservatively assumed that all sulfur oxides emissions are in the form of sulfuric acid mist because separate $\mathrm{SO}_{3}$ emission factors are not available.

In 2009, numerous small purchases totaling 2,995 lb of sulfuric acid were procured at the Laboratory. These numerous small purchases of sulfuric acid captured in ChemLog are assumed to be in aerosol form since the specific usage is unknown. Total purchases do not exceed the otherwise use threshold. A summary of the threshold determinations for sulfuric acid is provided in Table 4-2. 
Table 4-2 Sulfuric Acid Threshold Determination for 2009

\begin{tabular}{lllll}
\hline \multicolumn{1}{c}{ Description } & \multicolumn{1}{c}{$\begin{array}{c}\text { Amount of } \\
\text { Sulfuric Acid (lb) }\end{array}$} & \multicolumn{1}{c}{ Data Source } & $\begin{array}{c}\text { EPCRA Section } 313 \\
\text { Activity } \\
\text { Determination }\end{array}$ & $\begin{array}{c}\text { EPCRA Section } 313 \\
\text { Activity Threshold } \\
\text { (lb) }\end{array}$ \\
\hline $\begin{array}{l}\text { Demineralizer } \\
\text { Regeneration and } \\
\text { Water Analysis at } \\
\text { the SWSC Plant }\end{array}$ & 73.1 & Site Support Contractor Logs & $\begin{array}{c}\text { Not in aerosol form } \\
\text { and not subject to } \\
\text { EPCRA Section } 313\end{array}$ & NA \\
$\begin{array}{l}\text { TA-3-22 } \\
\text { Demineralizer } \\
\text { Regeneration }\end{array}$ & 2,859 & Site Support Contractor Logs & & \\
$\begin{array}{l}\text { Storage Tank Air } \\
\text { Emissions }\end{array}$ & 0.003 & EPA, Tanks 4.0 Software & Manufactured & 25,000 \\
$\begin{array}{l}\text { Fuel Combustion } \\
\text { Byproducts }\end{array}$ & 10.36 & AP-42 and fuel use records & & \\
$\begin{array}{l}\text { Asphalt Plant } \\
\text { Production }\end{array}$ & 4.0 & AP-42 and facility records & & \\
$\begin{array}{l}\text { Natural Gas } \\
\text { Combustion }\end{array}$ & 604 & AP-42 and facility records & & \\
$\begin{array}{l}\text { Procurement Not } \\
\text { Evaluated }\end{array}$ & 2,995 & ChemLog & & \\
\hline
\end{tabular}

*Assumed to be in aerosol form.

\subsection{Polycyclic Aromatic Compounds (PACs)}

PACs are a chemical category included on the EPCRA Section 313 list as part of the PBT rule. The threshold for reporting PACs is $100 \mathrm{lb}$. Benzo(g,h,i)perylene is a PAC that has its own separate threshold. The threshold for benzo(g,h,i)perylene is $10 \mathrm{lb}$.

According to EPA's "EPCRA Section 313 Guidance for Reporting Toxic Chemicals: Polycyclic Aromatic Compounds Category" (EPA 2001b), fuel oil and paving asphalt contain PACs. In addition, PACs may be generated from the combustion of natural gas and fuel oil and the manufacture of asphalt. Each of these sources of PACs was evaluated and is described below.

\subsubsection{Procurement of PACs}

Under EPCRA Section 313, the PAC category includes 21 specific chemicals and an additional 51 chemical mixtures that are listed as potentially containing PACs. A search of the ChemLog dataset was done using CAS numbers for the 21 chemicals and text searches for the 51 chemical mixtures. No matches were identified and the total PACs from the ChemLog analysis for 2009 is zero. 


\subsubsection{PACs from Asphalt Production}

In 2009, the Laboratory's onsite asphalt plant produced approximately 1,339 tons of asphalt.

Additionally, Española Transit Mix provided 7,185 tons of asphalt amounts to LANL. Therefore, a total of 8,524 tons of asphalt was used at LANL in 2009.

A review of project management records for 2009 identified projects that involved the purchase of asphalt from outside contractors. Work tickets and project management records were reviewed to identify asphalt jobs that qualify as routine facility maintenance and are exempt under EPCRA Section 313. Routine facility maintenance includes patching of potholes, repair of roads and parking lots, and resurfacing of existing parking lots. These exempt activities resulted in 5,739 tons of asphalt being used. After reviewing these records, only three projects were identified that did not fall under the facility maintenance exemption. These projects used 2,785 tons of asphalt in 2009, which is non-exempt.

According to EPA guidance, asphalt tar (used in making asphalt) may contain as high as $178 \mathrm{ppm}$ of PACs (EPA 2001b). However, Chevron-Texaco, the supplier of the asphalt tar, provided information specific to their product (Chevron-Texaco 2001). The concentration of PACs in the asphalt tar is 8 ppm, which is significantly lower than the default value listed in the EPA's PACs guidance. The manufacturersupplied value was used in the calculation of PACs.

The Laboratory used a total of 874,637 lb of asphalt tar in asphalt production in 2009 for Laboratory roads. Using the 8-ppm concentration, the total amount of PACs otherwise used at the Laboratory in all asphalt work in 2009 was $7 \mathrm{lb}$. The concentration of benzo(g,h,i)perylene in asphalt, from EPA's Guidance on PBTs, is $1.2 \mathrm{ppm}$ (EPA 2001c). This figure gives $1.05 \mathrm{lb}$ of benzo(g,h,i)perylene reportable towards its $10-1 b$ otherwise use threshold.

\subsubsection{PACs from Fuel Oil Combustion}

Approximately 36,230 gallons of diesel fuel were used in 2009 in the Laboratory's power plant and miscellaneous boilers and generators. According to EPA guidance, fuel oil may contain 10 ppm of PACs (EPA 2001b). However, data provided by Chevron-Texaco indicate diesel may contain 22 ppm of PACs (Chevron-Texaco 2001). The 22-ppm value was used in these calculations. This equates to $5.66 \mathrm{lb}$ of PACs that apply to the otherwise use threshold. The concentration for benzo(g,h,i)perylene was found to be 0.05 ppm according to EPA guidance (EPA 2001c). Data provided by Chevron-Texaco indicated concentrations of $9 \mathrm{ppm}$. The 9-ppm value was used in these calculations and results in $2.32 \mathrm{lb}$ of benzo(g,h,i)perylene applicable to the 10-lb otherwise use threshold.

Combustion of fuel oil generates emissions of PACs that apply to the manufacture threshold. Using AP42 emission factors (EPA 1998a), these amounts were calculated to be $6 \times 10^{-4} \mathrm{lb}$ for total PACs and $8.2 \times 10^{-5} \mathrm{lb}$ for benzo(g,h,i)perylene.

\subsubsection{PACs from Natural Gas}

Approximately 1,017.5 million standard cubic feet (MMscf) of natural gas were burned at the Laboratory facilities in 2009. Using AP-42 emission factors (EPA 1998b) and fuel records, approximately $0.017 \mathrm{lb}$ of PACs were produced from natural gas combustion, which is applied to the manufacture threshold.

Approximately $0.0012 \mathrm{lb}$ of benzo(g,h,i)perylene applies toward the 10-lb manufacture threshold. Due to the absence of information regarding total PAC and benzo(g,h,i)perylene concentrations in natural gas, it was assumed these substances are negligible in natural gas before combustion. 


\subsubsection{Summary of PACs}

The largest source of PACs at the Laboratory in 2009 was asphalt use. The total amount used from all sources is $12.68 \mathrm{lb}$. The total amount manufactured from combustion of fuel oil and natural gas is 0.018 lb. Both quantities for otherwise use and manufacture were below the 100-lb threshold, therefore, it was determined that reporting of PACs under EPCRA Section 313 was not necessary.

Benzo(g,h,i)perylene concentrations in asphalt tar and diesel fuel totaled $3.37 \mathrm{lb}$ towards the otherwise use threshold. Combustion processes accounted for $0.0013 \mathrm{lb}$, which is considered to be manufactured. These values are below the reporting threshold of $10 \mathrm{lb}$. Therefore, benzo(g,h,i)perylene reporting was not necessary under EPCRA Section 313 in 2009. Table 4-3 summarizes the PACs and benzo(g,h,i)perylene threshold determinations.

Table 4-3 LANL 2009 Threshold Determinations for PACs and Benzo(g,h,i)perylene

\begin{tabular}{llllll}
\hline $\begin{array}{c}\text { EPCRA Chemicall } \\
\text { Compound }\end{array}$ & \multicolumn{1}{c}{ Process or Material } & Amount (lb) & Total (lb) & $\begin{array}{c}\text { EPCRA Section } \\
\text { 313 Activity } \\
\text { Determination }\end{array}$ & $\begin{array}{c}\text { EPCRA Activity } \\
\text { Threshold (lb) }\end{array}$ \\
\hline Total PACs & Impurity in natural gas & 0.0 & 12.66 & Otherwise Used & 100 \\
& Asphalt tar & 7.0 & & & \\
& Impurity in fuel oil & 5.66 & & & \\
& Natural gas combustion & 0.017 & 0.018 & Manufactured & 100 \\
& Fuel oil combustion & $6 \times 10^{-4}$ & & & \\
\hline Benzo(g,h,i)perylene & Impurity in natural gas & 0.0 & 3.37 & Otherwise Used & 10 \\
& Asphalt tar & 1.05 & & & \\
& Impurity in fuel oil & 2.32 & & & \\
& Natural gas combustion & 0.0012 & 0.0013 & Manufactured & \\
& Fuel oil combustion & $8.2 \times 10^{-5}$ & & & \\
\hline
\end{tabular}

\subsection{Nitric Acid}

In general, nitric acid is used in high volume at the Laboratory every year. The main uses are research and development activities, sample preparation, plutonium processing, and the bioassay program. Small amounts of nitric acid are used for cleaning glassware. The total amount of nitric acid used at LANL in 2009 did not exceed the EPCRA Section 313 otherwise use threshold of 10,000 lb.

\subsubsection{Procurement}

Nitric acid procured and used at the Laboratory in 2009 was evaluated to determine the amounts that could be applied to the EPCRA Section 313 laboratory exemption. According to EPCRA Section 313 guidance documents, the laboratory exemption is applied to the quantity of a listed toxic chemical that is manufactured, processed, or otherwise used in a laboratory under the supervision of technically qualified personnel. However, quantities of a listed toxic chemical used for cleaning glassware do not qualify for this exemption. 
In 2009, a total of 8,778 $\mathrm{lb}$ of nitric acid was procured at the Laboratory, based on queries of the ChemLog system. Some of the purchase records indicate the nitric acid is actually $69 \%$ to $71 \%$ nitric acid in an aqueous solution, or more dilute solutions. In almost all cases, the nitric acid is purchased as "lab grade," which is $65 \%$ to $70 \%$ nitric acid in water. The concentration of the nitric acid purchases was taken into account and the resulting amount of pure nitric acid purchased was calculated to be $6,277 \mathrm{lb}$.

Plutonium Manufacturing and Technology (PMT) Division is the largest user of nitric acid and they had very limited operations due to facility and maintenance upgrades. Historically, PMT Division purchases nitric acid in bulk and stores it in a nitric acid storage tank. However, in 2009 no additional nitric acid was purchased for the tank, and very little nitric acid was used from the tank inventory.

Other large users of nitric acid were contacted to determine how the nitric acid was used. Relatively large quantities of nitric acid continue to be used for the bioassay program (monitoring employees for radioactive elements). Numerous other users within the Chemistry Division were contacted and verified the use of nitric acid for sample preparation and analysis. In 2009, this use totaled 4,375 lb. Information was also obtained on the approximate amount of nitric acid used for cleaning laboratory glassware, which is not considered a laboratory exempt activity. The total amount calculated to be used for cleaning glassware was $150 \mathrm{lb}$.

The quantity of nitric acid used by personnel that were not contacted (except for PMT Division, which is described in Section 4.4.2) or that described their use of nitric acid as process related (including cleaning glassware) totaled 1,902 lb. As a conservative assumption, this amount is assumed to be otherwise used.

\subsubsection{PMT Plutonium Processing}

Plutonium processing facility management was contacted to obtain information on the amount of nitric acid used in plutonium processing in 2009. PMT did not purchase any bulk nitric acid for their bulk storage tank in 2009. Facility management provided information that 2,000 liters of nitric acid were used in 2009 and was approximately 14-15 molar (70\%) solution of nitric acid in water. From MSDS review, the density for $70 \%$ nitric acid solution is $11.5 \mathrm{lb}$ per gallon, therefore the amount of nitric acid actually used at PMT was $6.077 \mathrm{lbs}$.

\subsubsection{Summary}

Nitric acid use in 2009 is below the EPCRA 313 10,000-lb otherwise use threshold and, therefore, is not reportable. Table 4-4 provides a summary of nitric acid use at LANL in 2009. 
Table 4-4 Nitric Acid Threshold Determination for 2009

\begin{tabular}{lccc}
\hline \multicolumn{1}{c}{ Description } & $\begin{array}{c}\text { Amount of } \\
\text { Nitric Acid (lb) }\end{array}$ & $\begin{array}{c}\text { EPCRA Section 313 } \\
\text { Activity Determination }\end{array}$ & $\begin{array}{c}\text { EPCRA Section } 313 \\
\text { Activity Threshold (lb) }\end{array}$ \\
\hline $\begin{array}{l}\text { Laboratory Use } \\
\text { Otherwise Use }\end{array}$ & 4,375 & Lab Exempt & Exempt \\
- Non-Lab, or unknown use & 1,902 & Otherwise Use & \\
- Plutonium Processing & & & \\
$\quad$ (PMT actual use) & 6,077 & & 10,000 \\
Total Otherwise Use & 7,979 & &
\end{tabular}

\subsection{Nitrate Compounds}

According to the EPA's EPCRA Section 313 Guidance "List of Toxic Chemicals within the Water Dissociable Nitrate Compounds Category and Guidance for Reporting" (EPA 2000a), nitrate compounds may be manufactured through the elemental neutralization of nitric acid and through the collection and treatment of sanitary wastewater. These sources of nitrate compounds are applicable to the Laboratory and are discussed in this section. The reporting thresholds for nitrate compounds are 25,000 lb for manufacture/import or process and 10,000 lb for otherwise used. Only the manufacture and otherwise use thresholds apply to the Laboratory for 2009 EPCRA reporting.

The above listed guidance provides a list of approximately 50 nitrate compounds that are included as water dissociable nitrate compounds. Although this list is not exhaustive, it provides commonly identified nitrate compounds. Only those compounds in aqueous solution (>50\% water) are required to be reported. Also, a de minimis concentration of $1 \%$ is applied to all nitrate compounds found in mixtures. When determining the reporting threshold for nitrate compounds, the entire nitrate compound is included (both the nitrate and its counter ion) toward determining the threshold. If the threshold is exceeded, only the nitrate portion of the compound is reported.

For the manufacture threshold, the sources reviewed included waste nitric acid treated at the Radioactive Liquid Waste Treatment Facility (RLWTF), which uses sodium hydroxide in an elementary neutralization process. The other source was the SWSC Plant. The nitrate compounds that were applied to the otherwise use threshold included nitrate compounds purchased or used during 2009. Other nitrate compounds evaluated were determined to be non-aqueous and were not required to be included in threshold determinations.

\subsubsection{Chemical Review}

A query of ChemLog was performed to determine the amount of chemicals applied to the otherwise use threshold. Approximately 5,208 lb of nitrate compounds were purchased in 2009. A few of the larger quantity purchases were clearly nitrate compounds in a powder (non-aqueous) form and do not count towards the EPCRA threshold. These purchases were removed from the threshold totals. The revised total purchases of nitrate compounds that were counted towards the otherwise use threshold for 2009 equals $136.5 \mathrm{lb}$. As a conservative assumption, it is assumed these are in aqueous form and apply to the otherwise use threshold. 


\subsubsection{Sanitary Wastewater}

The SWSC Plant collects sanitary wastewater (sewage and other allowable discharges) from several LANL facilities and treats the wastewater in a standard primary (physical), secondary (biological) treatment system. Information was collected from the SWSC Plant on nitrate influent concentration and total flow rate for the purpose of EPCRA Section 313 threshold determination. The information provided indicated an average nitrate concentration of the influent of 1.35 milligrams per liter $(\mathrm{mg} / \mathrm{L})$ and total flow into the system during 2009 was 60,423,000 gallons.

Using the flow rate given by the plant, the total annual average amount of nitrate compound (as sodium nitrate) was calculated. At the average nitrate concentration of $1.35 \mathrm{mg} / \mathrm{L}$, and adjusting the weight to include the sodium ion, the total sodium nitrate processed as an impurity was $932 \mathrm{lb}$ in 2009.

The information provided by the SWSC Plant also included the amount and the nitrate concentration of the effluent treated water. The total amount of treated water out of the SWSC Plant in 2009 was $85,289,000$ gallons. The average nitrate concentration was $1.8 \mathrm{mg} / \mathrm{L}$. This calculates to a total of $1,755 \mathrm{lb}$ of nitrates (as sodium nitrate) manufactured.

The SWSC Plant is a zero discharge facility and all treated water is kept in a holding pond and pumped to the TA-3 power plant for use in cooling towers. Therefore, there are no releases to the environment from the SWSC Plant.

\subsubsection{Nitric Acid Neutralization}

Typically, waste nitric acid from the mixed oxide (MOx) fuel process and from the Nitric Acid Recycling System, both located at the Plutonium Facility, is sent to the RLWTF for treatment. The RLWTF received 2,530 liters of nitric acid waste from the Plutonium Facility in 2009. The amount of nitrate compounds formed due to nitric acid treated at the RLWTF is usually calculated using the formula found in the EPA "Nitrate Compound Guidance" (EPA 2000a). However, no waste was treated during 2009 by the RLWTF because equipment and piping are being replaced in the Room 60 Upgrades Project. The nitric acid waste received is still being held in a holding tank.

\subsubsection{Summary}

Nitrate compounds that apply to the otherwise use threshold of $10,000 \mathrm{lb}$ include the chemicals found in ChemLog. A total of $136.5 \mathrm{lb}$ of nitrate compounds was purchased and assumed to be in aqueous form. This is well below the 10,000-lb EPCRA Section 313 threshold.

Nitrate compounds that apply to the manufacture threshold of 25,000 lb include those identified in the sanitary wastewater at the SWSC Plant and the nitrate compounds identified during the elementary neutralization of nitric acid at the RLWTF. However, in 2009 the RLWTF did not operate due to maintenance activities. The activity at the SWSC Plant totaled 1,755 lb of nitrate compounds manufactured. The amount of nitrate compounds processed as an impurity from this activity was $932 \mathrm{lb}$. It was determined that no thresholds for nitrate compounds were exceeded in 2009. Table 4-5 provides a summary of nitrate compounds at LANL in 2009. 
Table 4-5 Summary of Nitrate Compounds at LANL in 2009

\begin{tabular}{lccc}
\hline \multicolumn{1}{c}{ Description } & Amount (lb) & $\begin{array}{c}\text { EPCRA Section 313 Activity } \\
\text { Determination }\end{array}$ & $\begin{array}{c}\text { EPCRA Section } 313 \\
\text { Threshold (lb) }\end{array}$ \\
\hline $\begin{array}{l}\text { Purchased in ChemLog (assumed in } \\
\text { aqueous form and otherwise used) }\end{array}$ & 136.5 & Otherwise Used & $10,000 \mathrm{lb}$ \\
$\begin{array}{l}\text { Processed at SWSC Plant } \\
\text { Manufactured at SWSC Plant }\end{array}$ & 932 & Processed & $25,000 \mathrm{lb}$ \\
Manufactured at RLWTF & 1,755 & Manufactured & $25,000 \mathrm{lb}$ \\
& 0 & & \\
\hline
\end{tabular}

\subsection{Hydrochloric Acid}

Hydrochloric acid $(\mathrm{HCl})$ is purchased for numerous processes and is also generated as a combustion byproduct. The total amount of $\mathrm{HCl}$ procured in 2009 was $6,177 \mathrm{lb}$. This quantity includes aqueous forms of $\mathrm{HCl}$, not just aerosol forms. To be conservative, the entire amount was assumed to be in an aerosol form and was evaluated against the 10,000-lb otherwise use threshold, which it did not exceed. Therefore, it was not necessary to report $\mathrm{HCl}$ in 2009.

\subsection{DEHP}

A capacitor bank located at TA-55 contains 18 capacitors that hold 1.8 gallons of GE Dilektrol oil each for a total of 32.4 gallons. A major component of the Dilektrol oil is di-(2-ethylhexyl) phthalate or DEHP. This material is reportable under EPCRA 313.

The threshold for DEHP is 10,000 lbs and capacitors are article exempt. Therefore, based on the quantity contained in the capacitor bank and the article exemption, DEHP is not reportable in 2009.

\subsection{Dioxins}

Dioxins are a group of PBTs formed during combustion processes. The EPCRA Section 313 reporting threshold for the dioxins category is 0.1 gram manufactured, processed, or otherwise used. This limit applies to toxic-equivalent compounds, a category of dioxins consisting of 17 specific dioxin and dioxinlike compounds. These "compounds with chlorine substitution in the 2, 3, 7, 8-positions on the molecule are reportable under the EPCRA Section 313 dioxin and dioxin-like compounds category" (EPA 2000b).

Activities at the Laboratory that were evaluated for dioxins include explosives activities and fuel combustion. Each is described below.

\subsubsection{Explosives Activities}

Dioxins are formed by burning chlorine-based chemical compounds with hydrocarbons producing an unintentional byproduct in many industrial processes involving chlorine. One potential source of dioxin formation at the Laboratory is open burn/open detonation (OB/OD) of high explosives (HE). This is because many binders and plasticizers found in HE materials have chlorine in their chemical make-up. Therefore, analysis of HE materials and associated binders/plasticizers was performed to estimate dioxin emissions. 
Information on HE materials, such as explosive type, explosive name, composition, and chemical formula, was obtained from Laboratory personnel and textbooks. Some HE materials contain binders and plasticizers. These binders and plasticizers were evaluated and screened for those that contained chlorine. For those chlorine-containing binders/plasticizers, the weight percent chlorine in each was determined and the HE materials having chlorine-containing binders were further evaluated. Knowing the weight percent binder/plasticizer in these explosives and the weight percent chlorine in each binder, the amount of binder and amount of chlorine in each HE material containing chlorine was determined. Due to the unique nature of these materials, no specific dioxin emission factors are available. Therefore, a dioxin emission factor for burning of polyvinyl chloride in accidental fires was used to estimate dioxin emissions from burning of the chlorine-containing materials (ASME 1995). An emission factor of 4 micrograms $(\mu \mathrm{g})$ dioxin emitted per ton of material burned was used.

Based on available information, estimated emissions from dioxins formed by OB/OD of HE materials totaled $5.63 \times 10^{-8}$ grams in 2009. Furthermore, burning of HE materials at the LANL Burn Ground was evaluated separately for dioxin formation. A more conservative approach was used to estimate dioxin emissions from burning of HE materials. The assumption was made that all HE-contaminated waste could potentially result in dioxin formation. Emission factors developed by the EPA for the burning of ammonium perchlorate propellant were used (EPA 1998c). Based on estimating emissions from all waste materials burned, dioxin emissions were $9.97 \times 10^{-5}$ grams in 2009 .

\subsubsection{Fuel Combustion}

The Laboratory burns natural gas and diesel fuel in numerous boilers, heaters, and generators. No emission factors for dioxins were found for natural gas combustion. However, EPA EPCRA guidance for dioxins provides an emission factor of 3,178.6 picograms per liter of diesel fuel burned (EPA 2000b). The Laboratory burned a total of 36,230 gallons (137,145 liters) of diesel fuel in 2009. Multiplying by the dioxin emission factor, a total of $435.9 \mu \mathrm{g}$ (0.00044 grams) of dioxin was calculated to have been formed from fuel combustion.

The total calculated dioxin emissions in 2009 are below the 0.1 -gram threshold and, therefore, reporting under EPCRA Section 313 is not required. Table 4-6 summarizes the amount of dioxins formed from all sources characterized for 2009.

Table 4-6 Dioxin Threshold Determination for 2009

\begin{tabular}{llll}
\hline \multicolumn{1}{c}{ Description } & \multicolumn{1}{c}{$\begin{array}{c}\text { Amount of Dioxin Formed } \\
\text { (grams) }\end{array}$} & $\begin{array}{c}\text { EPCRA Section 313 } \\
\text { Activity Determination }\end{array}$ & $\begin{array}{c}\text { EPCRA Section 313 } \\
\text { Threshold (grams) }\end{array}$ \\
\hline HE Expended & $5.63 \times 10^{-8}$ & Manufactured & 0.1 \\
HE Burned & $9.97 \times 10^{-5}$ & Manufactured & 0.1 \\
Fuel Combustion & $4.4 \times 10^{-4}$ & Manufactured & 0.1 \\
Total Dioxin Formed & $\mathbf{0 . 0 0 0 5}$ & & $\mathbf{0 . 1}$ \\
\hline
\end{tabular}




\subsection{LEAD AND FORM R REPORTING}

\subsection{Threshold Determination}

Lead and lead compounds are used in various processes throughout the Laboratory. In January 2001, the EPA promulgated a rule lowering the threshold for EPCRA Section 313 reporting of lead and lead compounds to $100 \mathrm{lb}$, effective for reporting year 2001. In 2009, lead and lead compounds were used or manufactured in the following operations at the Laboratory.

\subsubsection{Lead Procurements}

A listing of all procurements in 2009 of lead and lead compounds was extracted from ChemLog. Line items containing a CAS number for lead (7439-92-1) were included, as well as any line items containing the word "lead" or the symbol " $\mathrm{Pb}$ " in the text description.

The total amount of lead and lead compounds added to ChemLog for 2009 was $15.01 \mathrm{lb}$. Line items in ChemLog that were clearly described as lead standards were assumed to be used in a laboratory setting and exempt from reporting. This accounted for $11.3 \mathrm{lb}$. The total amount of lead and lead compounds from procurements applied to the otherwise use threshold is $3.8 \mathrm{lb}$.

\subsubsection{Lead Use at the Firing Range}

Lead is a component in various types of ammunition. The Laboratory maintains an onsite firing range for training security personnel. The firing range keeps detailed records of the amount and type of munitions expended. The U.S. Department of Defense developed software for estimating usage and releases of EPCRA Section 313 chemicals from various munitions activities (EPA www.epa.gov/tri). The TRI-Data Delivery System (TRI-DDS) software was used to calculate the amounts of toxic chemicals associated with munitions used at LANL for comparison with EPCRA Section 313 reporting thresholds and calculation of environmental releases. Some ammunition used at LANL was not represented in TRI-DDS. In these cases, the manufacturer was contacted to obtain specific information on lead for that ammunition.

The total lead released to the environment at the firing range in 2009 was slightly lower than previous years. Using the TRI-DDS software, it was determined that 5,000 lb of lead and $9.96 \mathrm{lb}$ of lead compounds were otherwise used.

The 2009 amount of lead released to land (non-air) was 5,000 lb. This amount equals the amount otherwise used. Lead compounds are also manufactured through the firing of ammunition. These lead compounds were calculated using the TRI-DDS software. Additionally, firing of ammunition containing lead created (manufactured) $4.9 \mathrm{lb}$ of lead compounds as air emissions.

\subsubsection{Lead from Fuel Combustion}

In 2009, the Laboratory emitted lead compound emissions from the following combustion sources: the TA-3 power plant, the TA-3 combustion turbine, and numerous small boilers, which used approximately 1,017.5 MMscf of natural gas. The AP-42 emission factor for lead compounds from natural gas combustion in both large and small boilers is $0.0005 \mathrm{lb} / \mathrm{MMscf}$. The lead compound emissions from these sources totaled $0.52 \mathrm{lb}$ towards the manufactured threshold. The Laboratory also burned an estimated 36,230 gallons of diesel fuel in boilers, heaters, and diesel-fired generators. The AP-42 emission factor for diesel fuel combustion is $0.00123 \mathrm{lb}$ per 1,000 gallons; this equates to $0.045 \mathrm{lb}$ of lead compound manufactured. 
Additionally, lead is found in fuel oil and natural gas as an impurity. According to EPA guidance (EPA 2001d), the concentration of lead in No. 2 fuel oil is $0.5 \mathrm{ppm}$ and in natural gas is 0.05 milligrams per cubic meter. The 36,230 gallons of fuel oil contained $0.13 \mathrm{lb}$ of lead and 1.017.5 MMscf of natural gas contained $3.14 \mathrm{lb}$ of lead, which are added to the otherwise use threshold.

\subsubsection{Lead from Asphalt Plant}

A total of 1,339 tons of asphalt were produced in 2009. The AP-42 emission factor for lead from hot mix asphalt plants is $8.9 \times 10^{-7} \mathrm{lb}$ per ton asphalt (EPA 2004). This equates to $0.001 \mathrm{lb}$ of lead compounds manufactured.

\subsubsection{Lead Use at LANSCE}

The Laboratory continues to maintain an inventory of lead shielding and lead bricks at LANSCE and other areas of the Laboratory. In recent years, the Laboratory has attempted to reduce the inventory by sending some of the lead offsite to be reused. According to the EPA's web-based TRI advanced training course presented by Science Applications International Corporation on May 10, 2005, "the recovery of a listed Section 313 chemical for further distribution in commerce or commercial use is 'processing' of that chemical." Also, materials sent offsite for direct "reuse" are not reported on Form R, but material sent offsite for recycling are reported on Form R in Part II, Section 6.2. The EPA considers the direct recirculation of a toxic chemical within a process or between processes without any intervening reclamation or recovery to be "reuse." Furthermore, "reclamation or recovery" does not include simple phase changing of the toxic chemical before further reuse (e.g., simple re-melting of scrap metal).

The process for shipping scrap metal for "reuse" has been centralized at the Material Recycle Facility (MRF), part of LANL's salvage process. The MRF stages the metal and coordinates pick-up by a metal recycling company. The MRF estimates that 2,250 lb of lead were shipped offsite for "reuse" in 2009.

The lead sent to the metal recycling company is considered processed because it is distributed for commercial use. The metal recycling company repackages the lead and then sends it to a lead smelter. Because the lead is simply re-melted, it is defined as "reused." Therefore, it will not be reported on the Form R in Part II, Section 6.2.

\subsubsection{Other LANL Operations Using Lead and Lead Compounds}

The Sigma Foundry, located at TA-3-66, melts lead in order to declassify parts. In 2009, the foundry melted a total of $6.6 \mathrm{lb}$ of lead. Using Emission Factors from AP-42, Section 12.11, Secondary Lead Processing, the melting of the $6.6 \mathrm{lb}$ of lead resulted in a total of $0.0004 \mathrm{lb}$ of stack air emissions.

In previous years, the Laboratory has conducted operations to decontaminate lead shielding and lead melting and cutting operations to form new shielding. Onsite processing of both of these activities was suspended in 2000. None of these activities occurred onsite at LANL in 2009.

The Laboratory installed a lead-bismuth test loop at LANSCE in 2001. The test loop contains approximately $8,000 \mathrm{lb}$ of lead bismuth. There were no additions of lead bismuth in 2009 . 


\subsubsection{Conclusion}

The largest source of lead use at the Laboratory is from the firing range, which accounted for 5,000 lb of lead towards the otherwise use threshold. Table 5-1 summarizes the threshold determination for lead and lead compounds for 2009. Based on these operations, it was determined that lead was processed and used over threshold quantities. However, lead compounds did not exceed the reporting threshold. Therefore, for 2009 reporting, a Form R will be completed only for lead.

Table 5-1 Summary of Threshold Determination for Lead and Lead Compounds for 2009

\begin{tabular}{|c|c|c|c|}
\hline Activity & Lead "Use"(Ib) & Lead Compound "Use"(lb) & Comments \\
\hline $\begin{array}{l}\text { Lead Purchases } \\
\text { (ChemLog) }\end{array}$ & 0 & 3.8 & $\begin{array}{l}\text { Otherwise Used } \\
15.1 \mathrm{lb} \text { purchased, } \\
11.3 \mathrm{lb} \text { Lab Exempt }\end{array}$ \\
\hline Firing Range & 5,000 & 9.96 & Otherwise Used \\
\hline Firing Range & 0 & 4.9 & Manufactured \\
\hline Fuel Combustion & 0 & 0.57 & $\begin{array}{l}\text { Manufactured (sum of } \\
\text { natural gas, diesel, and } \\
\text { propane from asphalt } \\
\text { plant) }\end{array}$ \\
\hline Fuel Combustion & 3.27 & 0 & Otherwise Used \\
\hline $\begin{array}{l}\text { Lead } \\
\text { Recycle/Resale } \\
\text { (sold to Ace Metals) }\end{array}$ & 2,250 & 0 & $\begin{array}{l}\text { Processed, all of it is } \\
\text { "reused" and not } \\
\text { reported on the Form } \\
\text { Rs }\end{array}$ \\
\hline $\begin{array}{l}\text { Lead Re-Use from } \\
\text { LANSCE (DOE } \\
\text { inter-complex } \\
\text { transfer) }\end{array}$ & 0 & 0 & Processed for re-use \\
\hline Sigma Foundry & 6.6 & 0 & Processed \\
\hline $\begin{array}{l}\text { TOTAL Nonexempt } \\
\text { Use }\end{array}$ & $\begin{array}{l}\text { Otherwise Use }-5,003.3 \\
\text { Processed }-2,266.0\end{array}$ & $\begin{array}{l}\text { Otherwise Use }-13.74 \\
\text { Processed }-0 \\
\text { Manufactured }-5,47\end{array}$ & $\begin{array}{l}\text { Reporting Thresholds } \\
=100 \mathrm{lb}\end{array}$ \\
\hline
\end{tabular}

\subsection{Environmental Releases and Offsite Disposal}

\subsubsection{Air Emissions}

Although most of the air emissions are in the form of lead compounds, the Laboratory has chosen to report the entire weight of the lead compound air emissions on the Form $\mathrm{R}$ for lead. 


\subsubsection{Firing Range}

The Laboratory operates a firing range onsite for security personnel training. Monthly records are maintained detailing the type and amount of ammunition used at the firing range. For EPCRA Section 313 reporting purposes, the ammunition records are input to the Department of Defense TRI-DDS software (EPA www.epa.gov/tri) to estimate the amount of EPCRA chemical used and released to the environment. Based on the results of the TRI-DDS software, a total of $4.9 \mathrm{lb}$ of lead compounds were emitted as fugitive air emissions from the firing range in 2009.

\subsubsection{Fuel Combustion}

In 2009, the Laboratory emitted lead compounds from the following combustion sources: the asphalt plant, the TA-3 power plant, generators, and numerous small boilers and heaters. Emissions from the burning of both natural gas and diesel fuel were calculated. The total emissions from these combustion sources totaled $0.52 \mathrm{lb}$ of lead compound stack emissions.

The Sigma Foundry, located at TA-3-66, melts lead in order to declassify parts. In 2009, the foundry melted a total of $6.6 \mathrm{lb}$ of lead. Using Emission Factors from AP-42, Section 12.11, Secondary Lead Processing, the melting of the $6.6 \mathrm{lb}$ of lead resulted in a total of $4 \times 10^{-5} \mathrm{lb}$ of stack air emissions.

\subsubsection{Conclusion}

In 2009, the Laboratory emitted a total of $5.42 \mathrm{lb}$ of lead to the atmosphere. The fugitive emissions are from the firing range. The stack emissions include emissions from fuel oil/diesel combustion sources and natural gas combustion sources and from the melting of lead at the Sigma Foundry. Table 5-2 summarizes lead air emissions from the Laboratory as reported on the Form R.

Table 5-2 Lead Air Emissions from LANL in 2009

\begin{tabular}{lll}
\hline Emission Source & Total Lead Emissions $(\mathbf{l b})$ & Fugitive or Stack \\
\hline Firing Range & 4.9 & Fugitive \\
Fuel Combustion & 0.52 & Stack \\
Sigma Foundry & 0.0004 & Stack \\
Total & $\mathbf{5 . 4 2}$ & \\
\hline
\end{tabular}

\subsubsection{Releases to Water}

This section describes the amount of lead released to the environment from the Laboratory during 2009, as measured at LANL's National Pollutant Discharge Elimination System (NPDES) outfalls, which quantifies the amount of listed chemicals released due to facility operations during the reporting period.

During prior year assessments, a second data source has been included in release estimates. The quantity of lead present in surface and storm water has been estimated and reported. These estimates were derived from analytical and flow volume data collected at surface water sampling stations, as well as flow estimates for stations where flow is not measured. Further calculations were performed to quantify the amount of lead attributable to naturally occurring sources, and then convert the anthropogenic fraction to derive a mass. The detailed methodology for the analysis of lead in surface and storm water and mass calculations is documented in annual EPCRA Summary Reports for calendar years 2001 through 2005. 
EPCRA requires the reporting of TRI listed chemicals released to the environment during the year in which they are originally released. The inclusion of surface and storm water data within the annual release dataset is an overestimate as these data do not represent current year releases, but measure the migration and transport of existing contaminant inventory that 1) was released to the environment before initiation of annual EPCRA reporting, 2) is unrelated to the original environmental release, and 3) cannot be differentiated from, and likely effectively masks, actual environmental releases. Therefore, annual EPCRA reporting will only include annual original release data as directly measured at NPDES outfalls.

NPDES outfall data, generated as part of the Laboratory's Outfall Monitoring Program, were obtained from the Water Quality and RCRA Group. The tabular data from the LANL's NPDES program included total annual flows and lead analytical results from samples collected at Outfall 051 at LANL. The new NPDES permit, August 1, 2007, only requires lead monitoring at this outfall and is now an annual sample, not weekly. The data for Outfall 051 under the new permit only includes one sample per year and that sample result was measured at just above the minimum quantification level with an analytical measurement result of $0.007 \mathrm{mg} / \mathrm{L}$.

For the EPCRA Section 313 Form R, Section 5.3 reporting, the total amount of lead released to each receiving stream is reported. For NPDES outfall data, the receiving stream associated with each sample location was determined through the use of the Laboratory's Environmental Surveillance Report maps and information received from LANL's Water Quality and RCRA Group. The following table summarized the total lead discharged from LANL in NPDES Outfall 051 within the Mortandad Tributary on the Pajarito Plateau during 2009. Total lead release to streams was $0.065 \mathrm{lb}$. Table 5-3 was used to complete Section 5.3.1 of the Form R.

Table 5-3 Lead Releases to Water in 2009 from LANL NPDES Outfall

\begin{tabular}{ll}
\hline Canyon & LANL NPDES Outfall Lead (lb) \\
\hline Mortandad Canyon Tributary to Rio Grande & 0.065 \\
Total of NPDES Discharges & $\mathbf{0 . 0 6 5}$ \\
\hline
\end{tabular}

\subsubsection{Releases to Land}

Lead releases to land at the Laboratory occur as a result of firing range activities. Lead releases to land are based on the amount of munitions used during the year and the lead content of the munitions used. Lead content for munitions used at the Laboratory was estimated by matching the munitions types with those listed in the TRI-DDS. A total of 5,000 lb of lead was released to land at the firing range at LANL in 2009.

\subsubsection{Offsite Waste Disposal}

The Solid Waste Operations Group provided waste characterization and disposal data for lead wastes that were shipped offsite in 2009. Laboratory and article exempt waste was removed from the dataset. EPCRA article and laboratory exemptions have been documented in previous years' memos and are described in the EPA/TRI Guidance Document "Toxic Chemical Release Inventory Reporting Forms and Instructions for RY2008” (EPA-260-K-08-001) (EPA 2008). 
The data provided by Solid Waste Operations included the percent of lead for most of the waste shipments. However, this information was lacking for many of the waste items, and the Ecology and Air Quality Group (now named the Environmental Stewardship Group) had to obtain the necessary information from MSDSs or the Merck Index (1989). In most cases, the waste profile form provided sufficient information to complete the lead calculation. For some waste items, estimates of the percent lead were made by matching it with similarly described waste shipments from previous years' analyses. For those waste items weighing less than 1 kilogram, lead concentrations were estimated based on the item description. For example, lead percentage by weight in waste items comprised of a chemical compound, such as lead nitrate, were determined from the Merck Index (1989). In other wastes, where the description provided sufficient information about the nature of the item (e.g., lead pellets), the percentage of lead was estimated (e.g., lead pellets $=100 \%$ lead). If the MSDS did not give the percentage of lead, the most conservative was assumed from the range given.

\subsubsection{Results}

The amount of lead contained in waste that was shipped offsite from the Laboratory in 2009 was 9,779 $1 \mathrm{~b}$. This total weight of lead was calculated by multiplying the total waste weight (kilograms) by the percentage of lead within each waste item, and then converted to pounds.

EPCRA reportable waste items shipped offsite from the Laboratory to several waste treatment/disposal facilities in 2009 are summarized in Table 5-4. As per EPCRA guidelines, only those disposal facilities that received more than $0.5 \mathrm{lb}$ of lead in 2009 were included in the summary table and on the Form R.

The 2009 totals for lead were higher than previous years, but significantly lower than amounts shipped offsite from LANL in 2003 and 2004. The increase in lead-containing waste shipments in 2009 was due to two waste streams that are periodically generated from the Laboratory. One is waste generated from the periodic cleanout of the sludge from the TA-50 Wastewater Treatment Plant (WWTP). The sludge cleanout of the WWTP settling ponds occurs every 3 to 5 years. The sludge is cemented in drums and disposed of as low-level waste. Approximately 845 drums of sludge with a lead content of $0.01 \%$ were shipped offsite in 2009. The other waste stream is the periodic cleanout from plutonium recovery research and development operations. In 2009, 1,936 containers of this waste stream were shipped offsite with an average lead content of $1 \%$.

\subsubsection{Disposal Fate}

The EPCRA Form R requires information about each treatment/disposal facility that received waste from the Laboratory, including how much was sent to each waste treatment/disposal facility and additional information regarding waste treatment, recycling, or disposal conducted at each facility. A Waste Disposal/Treatment Code must be entered in Section 6.2.C of the Form $\mathrm{R}$ for each facility receiving waste. The Waste Disposal/Treatment Codes were updated by the EPA in 2005 and are included on pages 54 and 55 of the "Toxic Chemical Release Inventory Reporting Forms and Instructions for RY2008" (EPA-260-K-08-001) (EPA 2008) guidance document. 
Table 5-4 Summary of Waste Disposal Facilities Receiving LANL Waste in 2009

\begin{tabular}{|c|c|c|c|c|}
\hline Company & Address & Facility EPA ID & Ultimate Fate of Waste & Total Lead (lb) \\
\hline $\begin{array}{l}\text { Clean } \\
\text { Harbors, } \\
\text { Aragonite, } \\
\text { LLC }\end{array}$ & $\begin{array}{l}11600 \text { North } \\
\text { Aptus Rd., } \\
\text { Aragonite, UT } \\
84029\end{array}$ & UTD981552177 & $\begin{array}{l}\text { Solidification/Stabalization of } \\
\text { metals }\end{array}$ & 2,654 \\
\hline $\begin{array}{l}\text { Clean } \\
\text { Harbors, El } \\
\text { Dorado, LLC }\end{array}$ & $\begin{array}{l}309 \text { American } \\
\text { Circle, El } \\
\text { Dorado, AR } \\
71730\end{array}$ & ARD069748192 & Landfill & 0.44 \\
\hline $\begin{array}{l}\text { Energy } \\
\text { Solutions, LLC }\end{array}$ & $\begin{array}{l}\text { Tooele County, } \\
\text { I-80, Exit } 49 \text {, } \\
\text { Clive, UT } \\
84029\end{array}$ & UTD982598898 & Landfill & 3,480 \\
\hline $\begin{array}{l}\text { Material and } \\
\text { Energy } \\
\text { Corporation }\end{array}$ & $\begin{array}{l}2010 \text { Highway } \\
58, \text { Suite 1020, } \\
\text { Oak Ridge, TN } \\
37830\end{array}$ & TNR000005397 & Landfill & 50 \\
\hline $\begin{array}{l}\text { Permafix } \\
\text { Northwest, } \\
\text { Inc. }\end{array}$ & $\begin{array}{l}2025 \text { Batelle } \\
\text { Rd, Richland, } \\
\text { WA } 99354\end{array}$ & WAR000010355 & "Other" Land Disposal & 3,496 \\
\hline $\begin{array}{l}\text { Perma-Fix, } \\
\text { Inc. }\end{array}$ & $\begin{array}{l}1940 \text { NW 67th } \\
\text { Place, } \\
\text { Gainesville, FL } \\
32653\end{array}$ & FLD980711071 & "Other" Land Disposal & 95 \\
\hline \multirow[t]{2}{*}{$\begin{array}{l}\text { Phibro-Tech, } \\
\text { Inc. }\end{array}$} & $\begin{array}{l}8851 \text { Dice Rd., } \\
\text { Santa Fe } \\
\text { Springs, CA } \\
90670\end{array}$ & CAD008488025 & Metal Recovery/Recycle & 3 \\
\hline & & Total & & 9,779 \\
\hline
\end{tabular}

\subsection{Other Information Provided on Form R Report}

Environmental releases of lead as air emissions, to surface waters, and onsite land releases were reported to be $5.42 \mathrm{lb}, 0.065 \mathrm{lb}$, and 5,000 lb, respectively. These values are included in Section 5 of the Form R, Quantity of the Toxic Chemical Entering Each Environmental Medium Onsite. A total of 9,799 lb of lead was reported in Section 6.2 of the Form R, Transfers to Other Offsite Locations.

Methods of treating lead in wastewater effluent before discharge were included in Section 7A of the Form $\mathrm{R}$, which details onsite waste treatment methods and efficiency. Wastewater from industrial processes at the Laboratory is discharged to the RLWTF before discharge to NPDES-permitted Outfall 051. The RLWTF conducts a series of treatment steps that reduce the amount of metals in the effluent. The wastewater stream goes through precipitation, filtration, and reverse osmosis treatment. All wastewater is sampled for lead before and after treatment. Based on analytical results for 2009, the RLWTF resulted in a $98.1 \%$ treatment efficiency of lead in the wastewater. Sections 7B and 7C of the Form R relate to onsite energy recovery and recycling. The Laboratory performed no onsite processes applicable to these sections for lead in 2009. 
Section 8 of the Form R refers to source reduction and recycling activities. The information provided by the EPA for this section states that no energy recovery is possible for lead, either onsite or offsite. The Laboratory also reported no onsite recycling or treatment.

Section 8.9 of the Form $\mathrm{R}$ reports the production or activity ratio, an estimated measure of production or activity involving the reported chemical, as compared to the previous year. Because the Laboratory is not a production facility, a surrogate measure was needed to complete this section of the Form R. To determine this value, the firing range was used as a representative activity that would maintain a consistent use of lead. The amount of lead munitions used in 2009 was divided by the amount used in 2008 to obtain an activity ratio of 0.7 .

\subsection{EPCRA SECTION 313 SUMMARY AND TRENDS}

The Laboratory has submitted EPCRA Section 313 data to the EPA since 1987. From 1987 to 1994, this information was submitted by the University of California, operator of LANL. Starting with reporting year 1995, EO 12856 required all federal facilities to comply with EPCRA Section 313 requirements. As of 1995, EPCRA Section 313 information for the Laboratory has also been submitted by the DOE. Historical information on LANL-reported Section 313 releases is included in the EPA TRI database and can be accessed at http://www.epa.gov/tri/.

On April 21, 2000, President Clinton signed EO 13148, which requires all federal facilities to comply with EPCRA Section 313 requirements and additionally requires federal facilities to reduce releases of EPCRA Section 313 chemicals to the environment. In response to EO 13148, the DOE developed Pollution Prevention Leadership Goals that include the following:

- Reduce release of toxic chemicals subject to Toxic Chemical Release Inventory (EPCRA Section 313) reporting by $90 \%$ by 2005 , using a 1993 baseline.

The Laboratory has implemented numerous pollution prevention projects to reduce use and releases of EPCRA Section 313 chemicals. However, two regulatory changes made by the EPA in recent years impact EPCRA Section 313 reporting:

- On October 19, 1999, the EPA promulgated a final rule on PBTs. This rule added several chemicals to the EPCRA Section 313 list and established lower reporting thresholds for PBT chemicals. These lower thresholds became applicable in reporting year 2000.

- On January 17, 2001, the EPA changed the PBT rule to reduce the EPCRA Section 313 reporting threshold for lead and lead compounds to $100 \mathrm{lb}$ (from 10,000 lb). The new lead threshold became applicable with reporting year 2001.

As a result of these regulatory changes, the Laboratory has triggered EPCRA Section 313 reporting for lead and mercury in recent years. The regulatory changes resulted in reporting thresholds of $10 \mathrm{lb}$ for mercury and $100 \mathrm{lb}$ for lead. Therefore, for the past seven years LANL has submitted environmental release data on lead and, three out of the last seven years, has reported on mercury. Figure 6-1 provides a summary of LANL-reported releases for the period from 1993 through 2009.

Several points are worth noting from this chart: 
- In the early 1990 s, the Laboratory implemented a new wastewater disinfection system that eliminated the use of chlorine. Chlorine gas was replaced with bromine tablets and mixed oxidants generated from sodium chloride. This pollution prevention project decreased use of chlorine to well below reporting thresholds.

- In the late 1990s, the Laboratory implemented a Nitric Acid Recycling System to reduce the amount of new nitric acid needed for plutonium processing. This closed-loop recycle system greatly reduced the need to purchase nitric acid, and due to recycling efforts, nitric acid use was below reporting thresholds for several years. However, in 2003 and 2004 a new process to convert weapons-grade plutonium to MOx fuels for nuclear power plants was implemented. Due to quality specifications and facility constraints, this project was unable to use recycled nitric acid. Therefore, nitric acid was reportable for 2003 and 2004.

- In 2005, the plutonium processing facility had very limited operations due to ongoing facility maintenance and equipment upgrades. Therefore, nitric acid use was well below reporting thresholds for 2005. In late 2006 the maintenance and equipment upgrades were completed and operations restarted. Nitric acid use for 2006 was still just below reporting thresholds. In 2007 nitric acid was again reportable due to resumption of higher levels of plutonium processing activities.

- Because there were no identified users of recycled nitric acid, and limited storage capacity, in 2004, spent nitric acid from plutonium processing was sent to the RLWTF for treatment and disposal. Through the treatment process nitric acid was neutralized and resulted in formation of nitrate compounds. For the first time in 2004, nitrate compounds were manufactured above reportable quantities and triggered reporting.

- Although the use of lead and lead compounds has been relatively constant over the years at the Laboratory, the threshold for reporting was lowered to $100 \mathrm{lb}$ in 2001. The Laboratory first began EPCRA Section 313 reporting on lead in that year. About that same time, LANL made a concerted effort to reduce onsite inventory of lead bricks and shielding that is no longer needed. Much of this lead shielding is radioactively contaminated and cannot be recycled. Therefore, large amounts of legacy lead were shipped offsite for disposal and reported on the Form Rs.

- The largest use of mercury at the Laboratory is in the LANSCE shutter system. Reservoirs of mercury are used as shields on the neutron beam shutter system. Each reservoir is a closed system and only opened occasionally when minor repairs or maintenance are needed. Mercury has only triggered reporting during the years that maintenance activities have occurred on the shutter systems. Environmental releases of mercury are very low. 


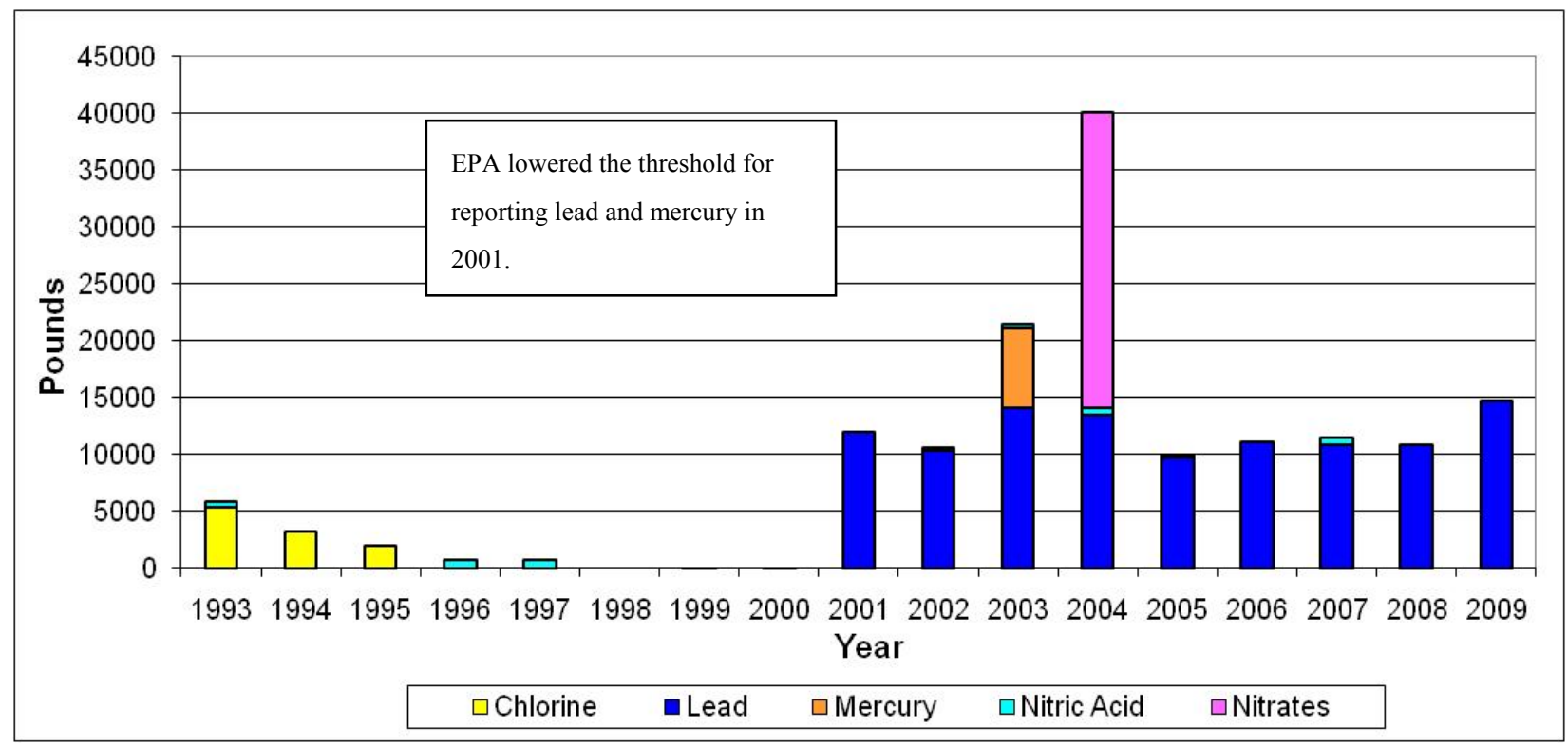

Note: For 2003 through 2006 one-time waste disposal of lead from decontamination and demolition activities is not included on this chart.

Figure 6-1 Trends in LANL's reported releases to EPA TRI. 


\subsection{REFERENCES}

ASME (American Society of Mechanical Engineers), 1995. "Relationship Between Chlorine in Waste Streams and Dioxin Emissions from Combustors," CRTD Vol. 36 (December 1995).

Chevron-Texaco, 2001. "Guidance Recommendations for SARA 313 Reporting of Polycyclic Aromatic Compounds (PACs) and Benzo(g,h,i)perylene" (May 2001).

EPA (U.S. Environmental Protection Agency), 1998a. "Compilation of Air Pollutant Emission Factors," AP-42, Chapter 1.3-Fuel Oil Combustion (September 1998).

EPA (U.S. Environmental Protection Agency), 1998b. "Compilation of Air Pollutant Emission Factors," AP-42, Fifth Edition, Section 1.4-Natural Gas Combustion (July 1998).

EPA (U.S. Environmental Protection Agency), 1998c. "Emission Factors for the Disposal of Energetic Materials by Open Burn and Open Detonation" (1998).

EPA (U.S. Environmental Protection Agency), 1999. "Emergency Planning and Community Right-toKnow Act-Section 313: Guidance for Reporting Hydrochloric Acid,” EPA 745-B-014 (December 1999).

EPA (U.S. Environmental Protection Agency), 2000a. "List of Toxic Chemicals within the Water Dissociable Nitrate Compounds Category and Guidance for Reporting," EPA 745-R-00-006 (December 2000).

EPA (U.S. Environmental Protection Agency), 2000b. "Emergency Planning and Community Right-ToKnow Act-Section 313: Guidance for Reporting Toxic Chemicals within the Dioxin and Dioxin-like Compounds Category,” EPA 745-B-00-021 (December 2000).

EPA (U.S. Environmental Protection Agency), 2001a. "EPCRA Mercury Guidance Document," EPA260-B-01-004, Table 3-1 (August 2001).

EPA (U.S. Environmental Protection Agency), 2001b. "Emergency Planning and Community Right-toKnow Act-Section 313: Guidance for Reporting Toxic Chemicals: Polycyclic Aromatic Compounds Category," EPA 260-B-01-03 (June 2001).

EPA (U.S. Environmental Protection Agency), 2001c. "Emergency Planning and Community Right-toKnow Act-Section 313: Guidance for Reporting Toxic Chemicals: Pesticides and Other Persistent Bioaccumulative Toxic (PBT) Chemicals," EPA 260-B-01-005 (August 2001).

EPA (U.S. Environmental Protection Agency), 2001d, "Emergency Planning and Community Right-toKnow Act-Section 313: Guidance for Reporting Releases and Other Waste Management Quantities of Toxic Chemicals: Lead and Lead Compounds," EPA 260-B-01-027 (December 2001).

EPA (U.S. Environmental Protection Agency), 2004. "Hot Mix Asphalt Plants," AP-42, Fifth Edition, Table 11.1-11 (March 2004).

EPA (U.S. Environmental Protection Agency), 2006. “Toxic Chemical Release Inventory Reporting Form R and Instructions,” Revised 2005 Version, EPA 260-B-06-001 (January 2006).

EPA (U.S. Environmental Protection Agency), 2008. “Toxic Chemical Release Inventory Reporting Forms and Instructions for RY2007,” EPA-260-K-07-001 (March 2008).

Merck Index, 1989. An Encyclopedia of Chemicals, Drugs, and Biologicals, Eleventh Edition. Merck and Co., Inc. Rahway, NJ. 
APPENDIX A: EPCRA SECTION 313 CHEMICALS USED OR PROCURED IN 2009

\begin{tabular}{|c|c|c|c|c|}
\hline CAS no. & Chemical Name & $\operatorname{Sec} 313$ & Threshold & Total (lbs) \\
\hline 7697-37-2 & Nitric acid & 313 & 10000 & 8534.17 \\
\hline 7647-01-0 & Hydrochloric acid (aerosol forms only) & 313 & 10000 & 6177.03 \\
\hline Nitrate & Nitrate compounds (water dissociable) & N511 & 10000 & 5208.15 \\
\hline $872-50-4$ & N-Methyl-2-pyrrolidone & 313 & 10000 & 3335.67 \\
\hline 7664-93-9 & Sulfuric acid (aerosol forms only) & 313 & 10000 & 2995.01 \\
\hline Cyanide & Cyanide Compounds & N106 & 10000 & 2313.62 \\
\hline $\begin{array}{l}\text { Polychlorinated } \\
\text { Alkanes }\end{array}$ & Polychlorinated alkanes (C10 to C13) & N583 & 10000 & 2009.19 \\
\hline $75-09-2$ & Dichloromethane & 313 & 10000 & 1927.62 \\
\hline $79-01-6$ & Trichloroethylene & 313 & 10000 & 847.26 \\
\hline $67-56-1$ & Methanol & 313 & 10000 & 686.9 \\
\hline $67-63-0$ & $\begin{array}{l}\text { Isopropyl alcohol (mfg-strong acid } \\
\text { process) }\end{array}$ & 313 & 10000 & 682.09 \\
\hline $78-93-3$ & Methyl ethyl ketone & 313 & 10000 & 663.55 \\
\hline $9016-87-9$ & Polymeric diphenylmethane diisocyanate & Diisocyanate & $<10000$ & 562.8 \\
\hline $108-88-3$ & Toluene & 313 & 10000 & 539.76 \\
\hline $110-54-3$ & n-Hexane & 313 & 10000 & 479.26 \\
\hline Silver & Silver Compounds & N740 & 10000 & 424.9 \\
\hline Glycol Ethers & Glycol Ethers & $\mathrm{N} 230$ & 10000 & 411.38 \\
\hline Manganese & Manganese Compounds & N450 & 10000 & 350.72 \\
\hline $7632-00-0$ & Sodium nitrite & 313 & 10000 & 306.25 \\
\hline $75-05-8$ & Acetonitrile & 313 & 10000 & 268.07 \\
\hline $95-63-6$ & 1,2,4-Trimethylbenzene & 313 & 10000 & 238.11 \\
\hline $7429-90-5$ & Aluminum (fume or dust) & 313 & 10000 & 200.62 \\
\hline $7664-41-7$ & Ammonia & 313 & 10000 & 196.53 \\
\hline $115-07-1$ & Propylene & 313 & 10000 & 166.88 \\
\hline $107-21-1$ & Ethylene glycol & 313 & 10000 & 154.75 \\
\hline $7664-39-3$ & Hydrogen fluoride & 313 & 10000 & 150.02 \\
\hline $1330-20-7$ & Xylene (mixed isomers) & 313 & 10000 & 139.25 \\
\hline $68-12-2$ & N,N-Dimethylformamide & 313 & 10000 & 90.42 \\
\hline Mercury & Mercury Compounds & Mercury N458 & 10 & 67.88 \\
\hline $1344-28-1$ & Aluminum oxide (fibrous forms) & 313 & 10000 & 64.55 \\
\hline $110-82-7$ & Cyclohexane & 313 & 10000 & 50.75 \\
\hline $75-45-6$ & Chlorodifluoromethane & 313 & 10000 & 50 \\
\hline $7664-38-2$ & Phosphoric acid & 313 & 10000 & 45.71 \\
\hline $123-31-9$ & Hydroquinone & 313 & 10000 & 43.84 \\
\hline 7783-06-4 & Hydrogen sulfide & 313 & 10000 & 41.66 \\
\hline
\end{tabular}




\begin{tabular}{|c|c|c|c|c|}
\hline CAS no. & Chemical Name & Sec 313 & Threshold & Total (lbs) \\
\hline $67-66-3$ & Chloroform & 313 & 10000 & 40.15 \\
\hline $51-79-6$ & Urethane & 313 & 10000 & 40 \\
\hline $74-85-1$ & Ethylene & 313 & 10000 & 37.48 \\
\hline Copper & Copper Compounds & N100 & 10000 & 31.38 \\
\hline $71-43-2$ & Benzene & 313 & 10000 & 30.88 \\
\hline $109-86-4$ & 2-Methoxyethanol & 313 & 10000 & 27.6 \\
\hline $10222-01-2$ & 2,2-Dibromo-3-nitrilopropionamide & 313 & 10000 & 22 \\
\hline $95-50-1$ & 1,2-Dichlorobenzene & 313 & 10000 & 18.75 \\
\hline $100-41-4$ & Ethylbenzene & 313 & 10000 & 14.8 \\
\hline Lead & Lead Compounds & N420 & 100 & 14.74 \\
\hline $106-42-3$ & p-Xylene & 313 & 10000 & 14.22 \\
\hline $56-23-5$ & Carbon tetrachloride & 313 & 10000 & 14.04 \\
\hline $101-68-8$ & Methylenebis(phenylisocyanate) & Diisocyanate & $<10000$ & 13.69 \\
\hline $77-73-6$ & Dicyclopentadiene & 313 & 10000 & 10.97 \\
\hline Zinc & Zinc Compounds & N982 & 10000 & 10.33 \\
\hline $75-56-9$ & Propylene oxide & 313 & 10000 & 10.23 \\
\hline Arsenic & Arsenic Compounds & N020 & 10000 & 10.12 \\
\hline Nickel & Nickel Compounds & N495 & 10000 & 9.95 \\
\hline $7440-38-2$ & Arsenic & 313 & 10000 & 9.16 \\
\hline $7726-95-6$ & Bromine & 313 & 10000 & 7.83 \\
\hline Cadmium & Cadmium Compounds & N078 & 10000 & 7.4 \\
\hline $91-20-3$ & Naphthalene & 313 & 10000 & 6.6 \\
\hline Chromium & Chromium Compounds & N090 & 10000 & 6.18 \\
\hline $110-80-5$ & 2-Ethoxyethanol & 313 & 10000 & 5.12 \\
\hline Barium & Barium Compounds & N040 & 10000 & 4.86 \\
\hline $108-31-6$ & Maleic anhydride & 313 & 10000 & 4.4 \\
\hline $121-44-8$ & Triethylamine & 313 & 10000 & 4.39 \\
\hline $\begin{array}{l}\text { Warfarin and } \\
\text { salts }\end{array}$ & Warfarin and salts & N874 & 10000 & 3.9 \\
\hline $108-90-7$ & Chlorobenzene & 313 & 10000 & 3.88 \\
\hline $108-38-3$ & m-Xylene & 313 & 10000 & 3.8 \\
\hline $74-88-4$ & Methyl iodide & 313 & 10000 & 3.63 \\
\hline Thallium & Thallium Compounds & N760 & 10000 & 3.54 \\
\hline $77-78-1$ & Dimethyl sulfate & 313 & 10000 & 2.93 \\
\hline Cobalt & Cobalt Compounds & N096 & 10000 & 2.79 \\
\hline $75-15-0$ & Carbon disulfide & 313 & 10000 & 2.78 \\
\hline $64-18-6$ & Formic acid & 313 & 10000 & 2.76 \\
\hline $78-92-2$ & sec-Butyl alcohol & 313 & 10000 & 2.23 \\
\hline
\end{tabular}




\begin{tabular}{|c|c|c|c|c|}
\hline CAS no. & Chemical Name & Sec 313 & Threshold & Total (lbs) \\
\hline $554-13-2$ & Lithium carbonate & 313 & 10000 & 2.2 \\
\hline $139-13-9$ & Nitrilotriacetic acid & 313 & 10000 & 2.2 \\
\hline $80-62-6$ & Methyl methacrylate & 313 & 10000 & 2.08 \\
\hline $100-42-5$ & Styrene & 313 & 10000 & 1.99 \\
\hline $75-65-0$ & tert-Butyl alcohol & 313 & 10000 & 1.89 \\
\hline $106-88-7$ & 1,2-Butylene oxide & 313 & 10000 & 1.8 \\
\hline $71-36-3$ & n-Butyl alcohol & 313 & 10000 & 1.78 \\
\hline $108-10-1$ & Methyl isobutyl ketone & 313 & 10000 & 1.75 \\
\hline $26628-22-8$ & Sodium azide $(\mathrm{Na}(\mathrm{N} 3))$ & 313 & 10000 & 1.54 \\
\hline $108-05-4$ & Vinyl acetate & 313 & 10000 & 1.48 \\
\hline $7440-36-0$ & Antimony & 313 & 10000 & 1.47 \\
\hline Chlorophenols & Chlorophenols & N084 & 10000 & 1.39 \\
\hline $98-95-3$ & Nitrobenzene & 313 & 10000 & 1.37 \\
\hline $120-80-9$ & Catechol & 313 & 10000 & 1.32 \\
\hline $110-86-1$ & Pyridine & 313 & 10000 & 1.2 \\
\hline $94-36-0$ & Benzoyl peroxide & 313 & 10000 & 1.1 \\
\hline Beryllium & Beryllium Compounds & N050 & 10000 & 1.07 \\
\hline Antimony & Antimony Compounds & N010 & 10000 & 1.07 \\
\hline Selenium & Selenium Compounds & N725 & 10000 & 0.58 \\
\hline $131-11-3$ & Dimethyl phthalate & 313 & 10000 & 0.55 \\
\hline $50-00-0$ & Formaldehyde & 313 & 10000 & 0.5 \\
\hline $302-01-2$ & Hydrazine & 313 & 10000 & 0.44 \\
\hline $123-38-6$ & Propionaldehyde & 313 & 10000 & 0.44 \\
\hline $7637-07-2$ & Boron trifluoride & 313 & 10000 & 0.42 \\
\hline $7440-41-7$ & Beryllium & 313 & 10000 & 0.4 \\
\hline 10294-34-5 & Boron trichloride & 313 & 10000 & 0.29 \\
\hline $108-95-2$ & Phenol & 313 & 10000 & 0.27 \\
\hline $105-67-9$ & 2,4-Dimethylphenol & 313 & 10000 & 0.26 \\
\hline $62-53-3$ & Aniline & 313 & 10000 & 0.24 \\
\hline 7723-14-0 & Phosphorus (yellow or white) & 313 & 10000 & 0.22 \\
\hline $123-72-8$ & Butyraldehyde & 313 & 10000 & 0.18 \\
\hline $106-93-4$ & 1,2-Dibromoethane & 313 & 10000 & 0.12 \\
\hline $80-05-7$ & 4,4'-Isopropylidenediphenol & 313 & 10000 & 0.11 \\
\hline $1313-27-5$ & Molybdenum trioxide & 313 & 10000 & 0.02 \\
\hline $7758-01-2$ & Potassium bromate & 313 & 10000 & 0.01 \\
\hline $99-30-9$ & Dichloran & 313 & 10000 & 0.01 \\
\hline $106-44-5$ & p-Cresol & 313 & 10000 & 0.01 \\
\hline $108-93-0$ & Cyclohexanol & 313 & 10000 & 0.01 \\
\hline
\end{tabular}




\begin{tabular}{|l|l|l|l|r|}
\hline \multicolumn{1}{|c|}{ CAS no. } & \multicolumn{1}{|c|}{ Chemical Name } & \multicolumn{1}{c|}{ Sec 313 } & Threshold & \multicolumn{1}{c|}{ Total (Ibs) } \\
\hline $137-26-8$ & Thiram & 313 & 10000 & 0.01 \\
\hline $108-39-4$ & m-Cresol & 313 & 10000 & 0.01 \\
$107-13-1$ & Acrylonitrile & 313 & 10000 & 0 \\
$120-12-7$ & Anthracene & 313 & 10000 & 0 \\
$121-14-2$ & $2,4-$ Dinitrotoluene & 313 & 10000 & 0 \\
$126-99-8$ & Chloroprene & 313 & 10000 & 0 \\
\hline
\end{tabular}


APPENDIX B: FORM R REPORT FOR LEAD (DOE AND LANL)

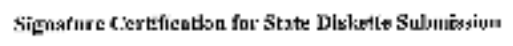

\title{
DISK
}

\author{
U.S. Depurtweal of Linergy \\ Los Alanos Nstional Laboiatnry \\ 3747 West Jemue Ro:ld

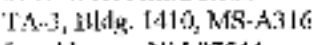 \\ I.os Alamos, NSL X.T544 \\ TRயШ: 37544STI.ST.52א1.
}

$X_{\text {en Shiiı }}$

TRI Cordinator

New Mexico Departmear of Hoinzlasd Securily

and E.ncręerey Sur.agunent.

P.O.Rux 2711

Santa Fc, NM 8750\%

To l.es Shin:

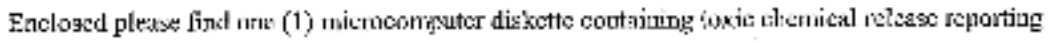

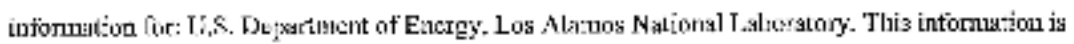

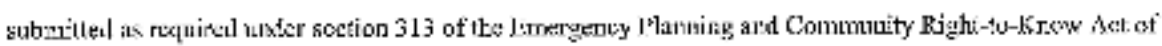

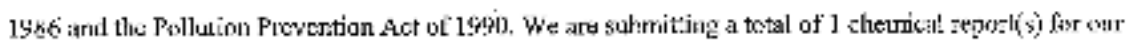

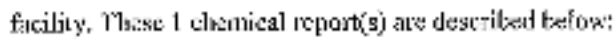

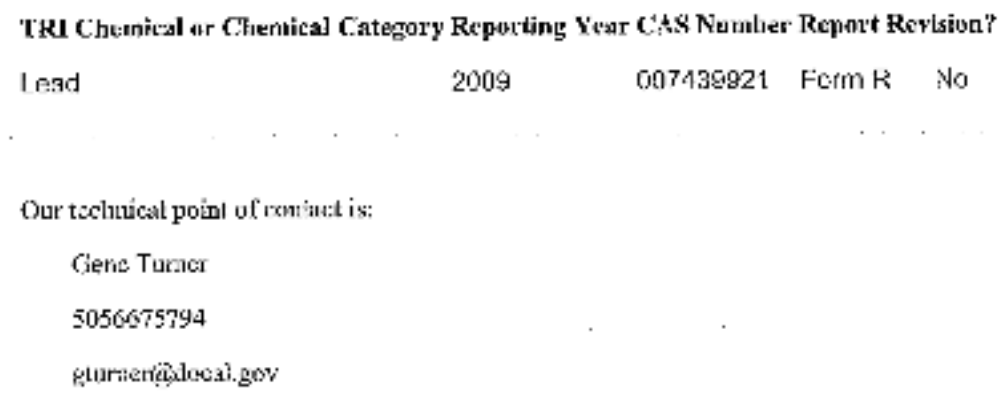

Page 2 


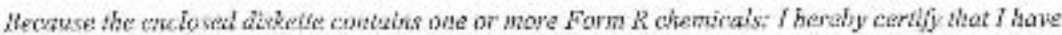

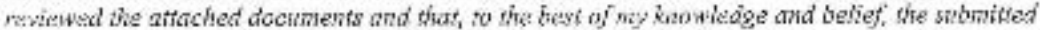

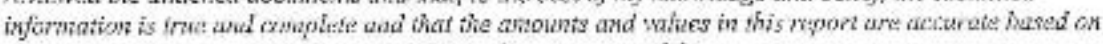

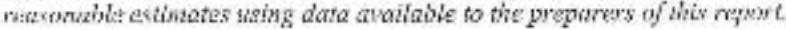

Sinocrely,

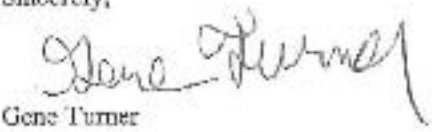

Esvitomental l'ermilling Manager

linclosure

I Visicette

$\mathrm{Cy}:$

G. Rat, DOE-L.ASO, A3I6

M. Mallory, PADOPS, A102

J. Cirtiwell, ADFSH\&O, K49!

C. Blackwell, LC-LESH, A187

1), 1 lierc:xut, ENV-DDO, J978

P. Gallagher, ENV-ES, J975

1). Jinnexily, F.VV F.S, J978

S. Story, ENV-ES, J978

W. Whetharm, EVV F.S, J978

EPCRA Projoct File, 5978

ENV-LAQ tile, 1978 


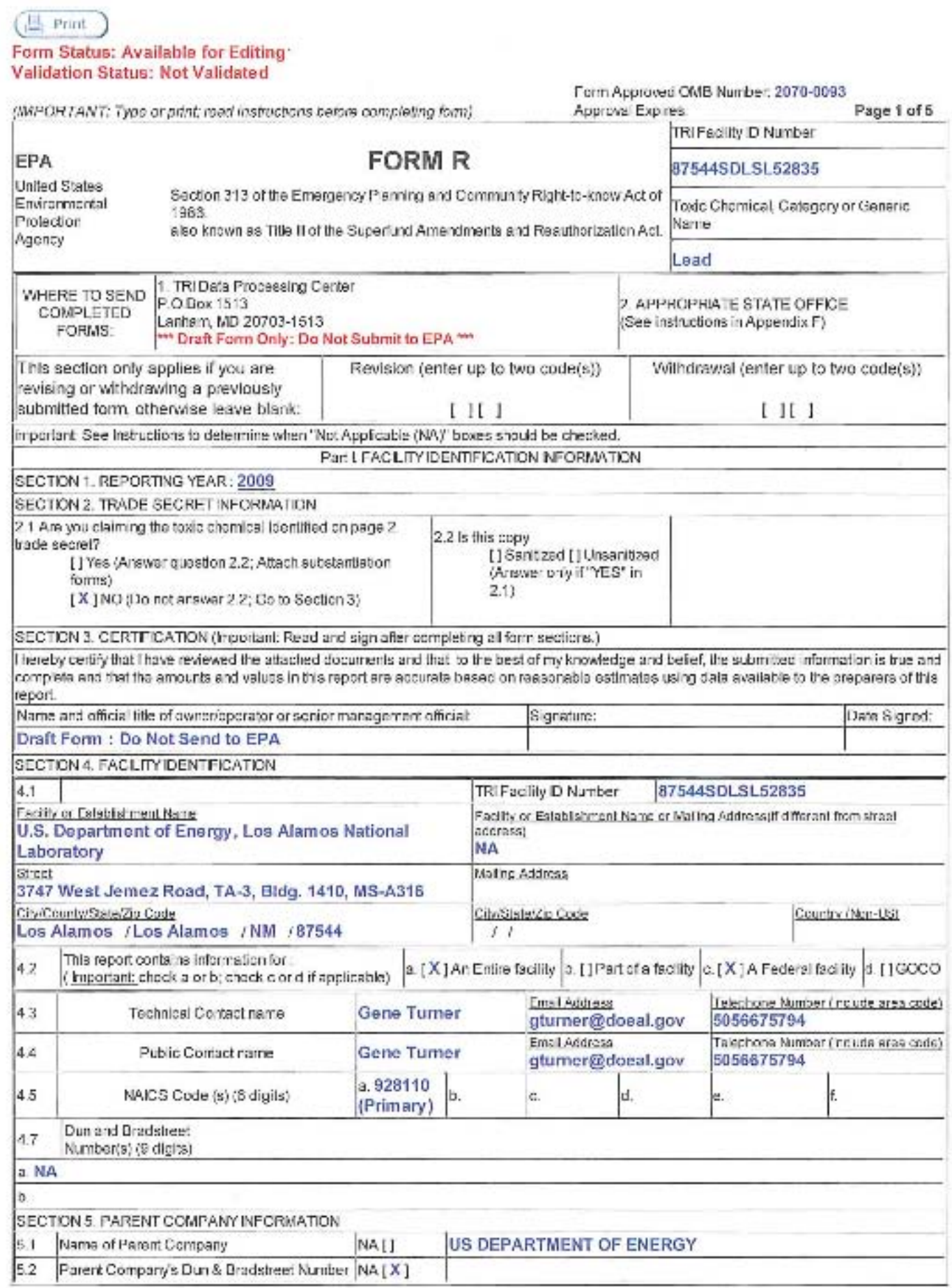


TRI Reportire Form

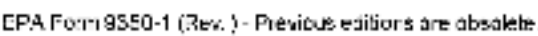

.

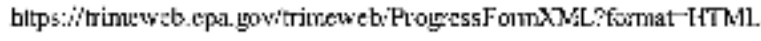

Prinked usitg TRIuLiarth 


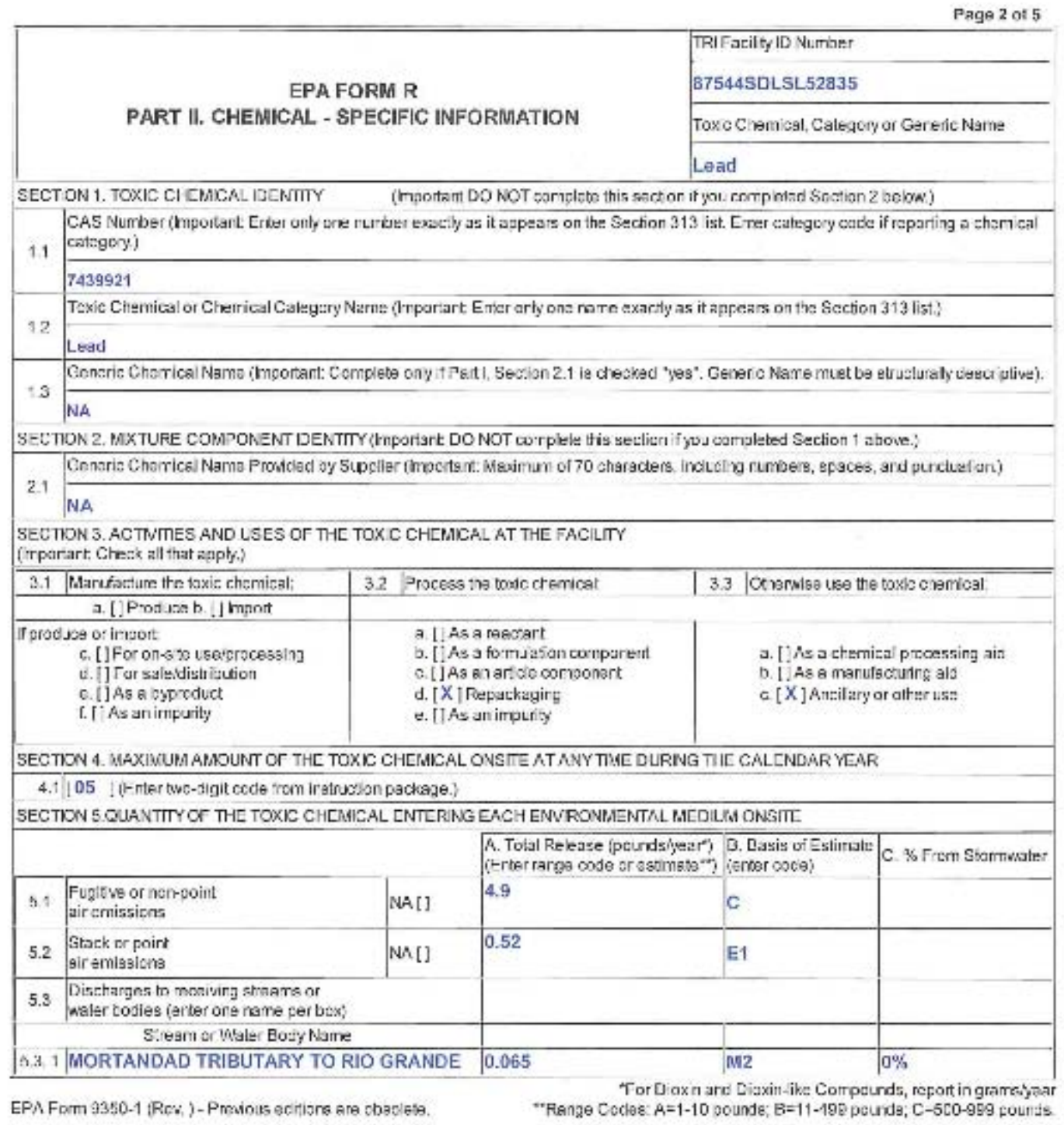




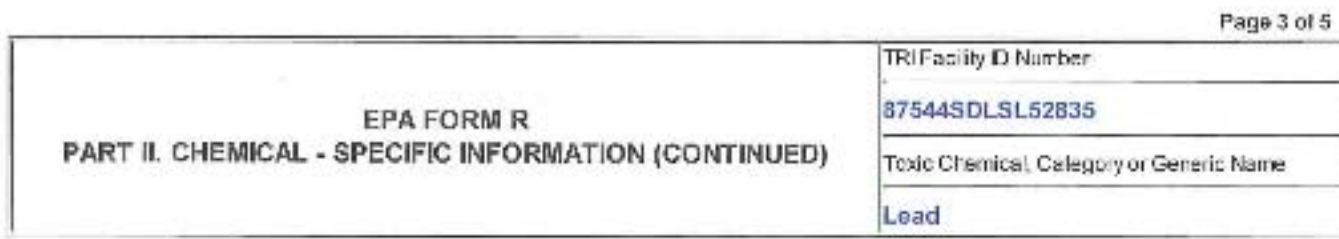

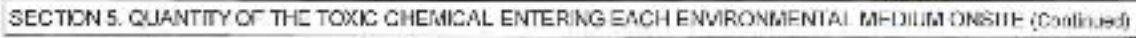

\begin{tabular}{|c|c|c|c|c|}
\hline & & MA & 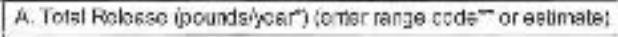 & B. Bess ol Estrireste ferler code! \\
\hline 5.4 .1 & $\begin{array}{l}\text { Underground irjection orrete } \\
\text { to Class I wonik }\end{array}$ & {$[X]$} & & \\
\hline 5.42 & $\begin{array}{l}\text { Underground rizection nereite } \\
\text { to Cless L-V vels }\end{array}$ & {$[\mathrm{K}]$} & & \\
\hline 5.5 & Dispasal bo bnd areite & & & \\
\hline $5.5,1, \mathrm{~A}$ & FC:RA subUUE C bandills & {$[X]$} & & \\
\hline $5.5 .1 . \mathrm{B}$ & Cother laratfils & {$[x]$} & & \\
\hline D.h 2 & $\begin{array}{l}\text { Laro tregtmentlapolication } \\
\text { ferrizg }\end{array}$ & {$[x]$} & & \\
\hline $5.5 .3 \mathrm{~A}$ & $\begin{array}{l}\text { RCRA Sibtitle C } \\
\text { surlace mpoundmerte }\end{array}$ & {$[x]$} & & \\
\hline $5.5 \mathrm{IH}$ & Other aurtace impoundrarts & IX: & & \\
\hline 5.5 .4 & Olher triegosal & Ii & 5000.5 & M2 \\
\hline \multicolumn{5}{|c|}{ SECTKXNE. TRANSFERS OF THE TOKX CHEMLAL NWASTES TO OTT-STL LOCATONS } \\
\hline \multicolumn{5}{|c|}{ 6.1 DISCHARGES TO PUBLKLYY OWNED TREATMENT WORKS (POTWS) } \\
\hline \multicolumn{5}{|c|}{ 5.1 A. Tolal Qugit:y Trensfereo to FOTis are Bas s o/Cslirsile } \\
\hline \multirow{2}{*}{\multicolumn{2}{|c|}{$\begin{array}{l}\text { 6.1 A.1 Total Transters (poundshyear) } \\
\text { ierber rarge code"- er estimalz) }\end{array}$}} & & 6.1A.2 & $\begin{array}{l}2 \text { Gesis of Eslimal: } \\
\text { (enter code) }\end{array}$ \\
\hline & & NA & & \\
\hline
\end{tabular}




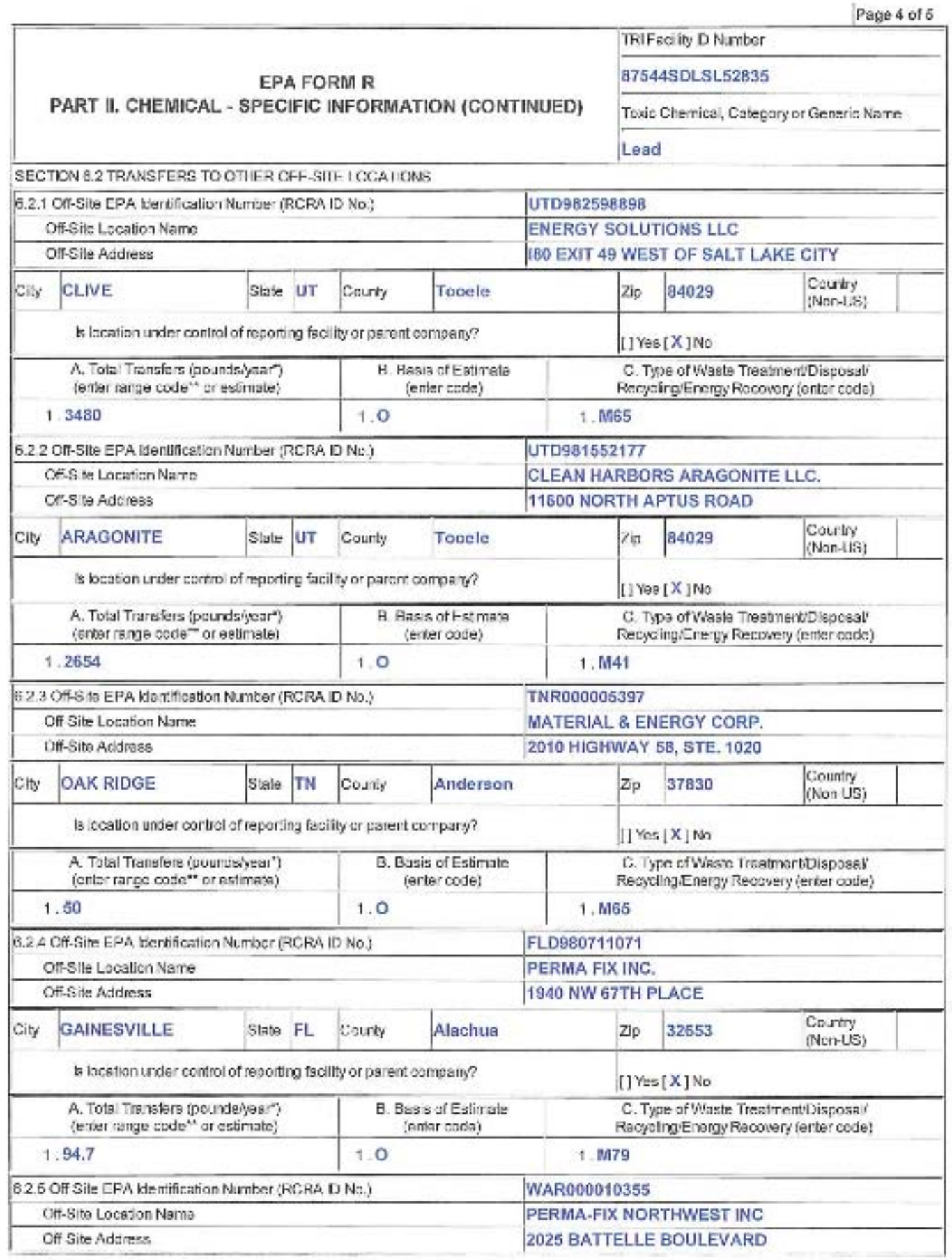




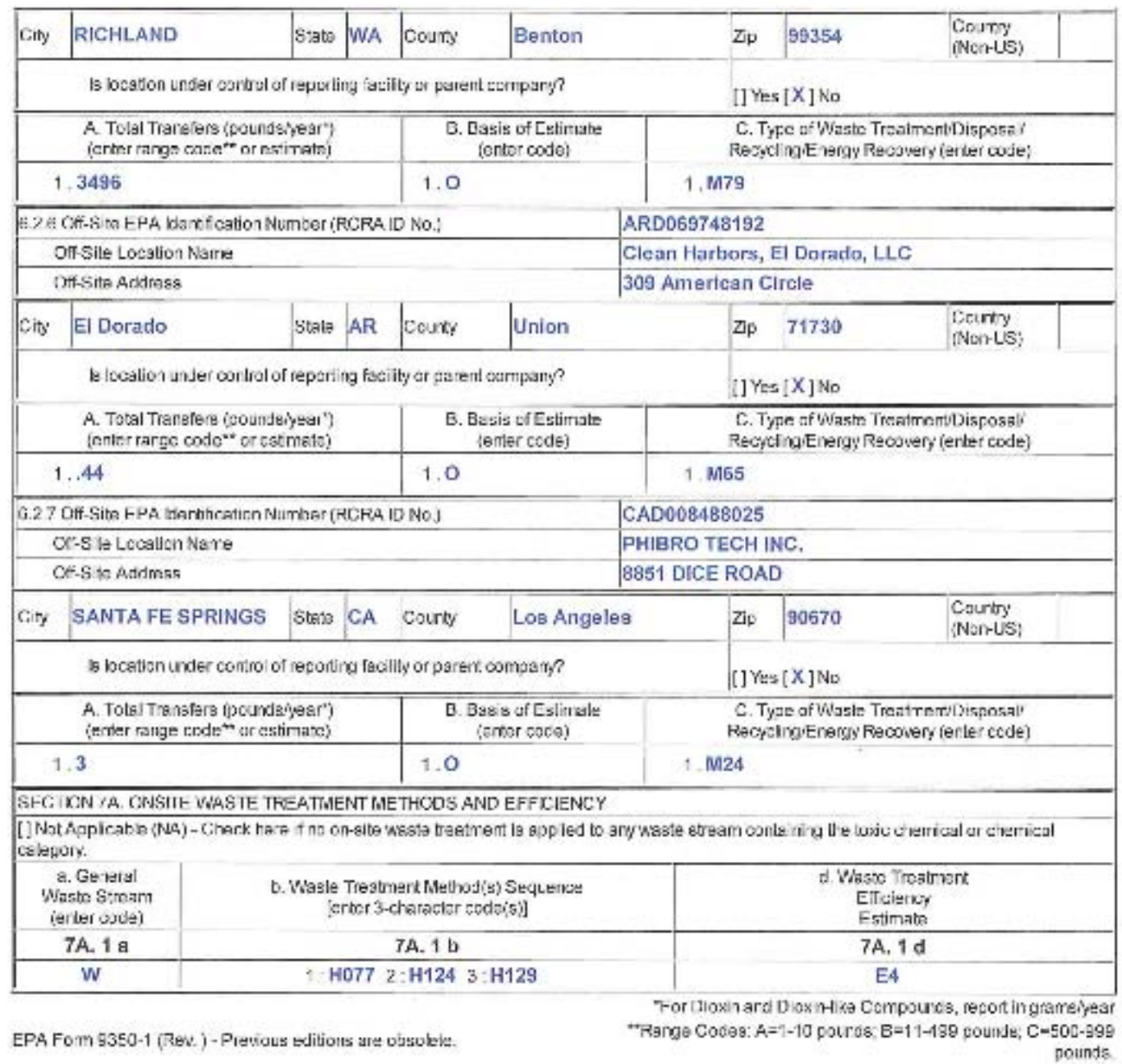




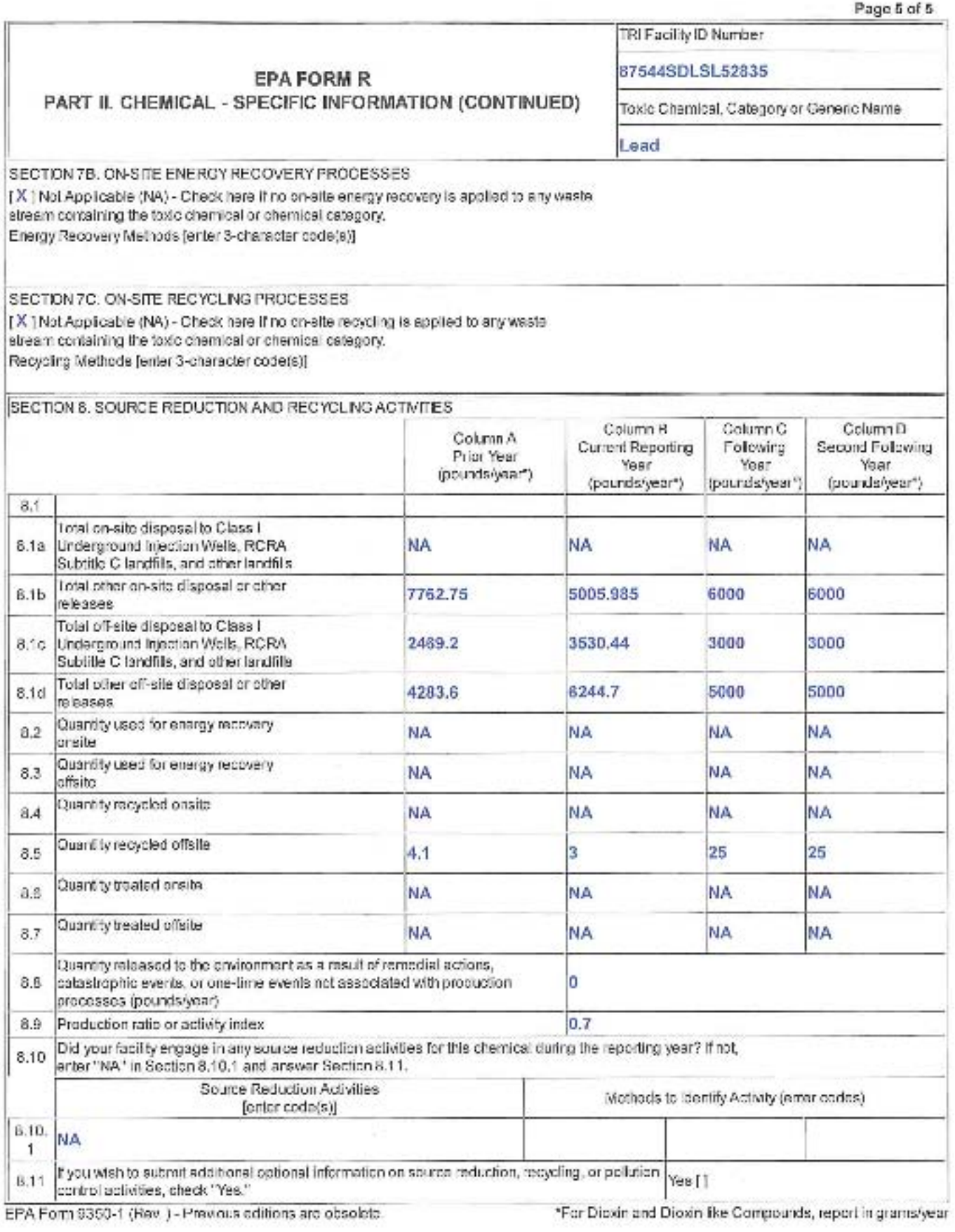




\begin{tabular}{|l|}
\hline TRI Tacily D NLmiter \\
\hline 87544SDLSL52835 \\
\hline Tane Chamcal Category o Geraric Narte \\
\hline Load \\
\hline
\end{tabular}

Additional optional information on source reduction, recycling, or pollution control activitites. 


\section{DISK}

Lo3 Nomos Narisnal Sowurity, LLC

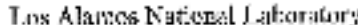

Bikiut $A$ toll lad SM30

T.us: Alanws, NM1 sis 45

TRIFID: 8754 ISTIMSIOSAL

T.zE Shiı

TRL Cooriviator

New Mexico Department of Ilomeland Socurity

and Lowergency Nian gement

P.O.Box 23III

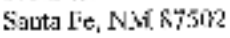

To Lec Slriv:

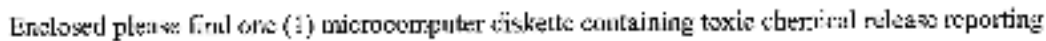

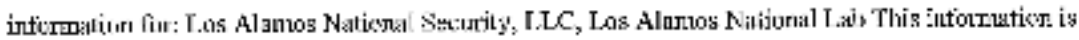

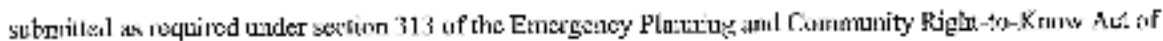

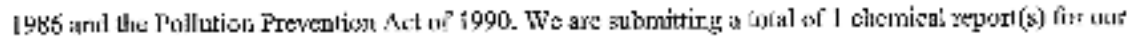

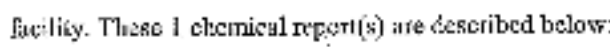

TRI Chemital or Chemical Catnessry Reporthy Foar CAS Number Report Revision?

Ort toclunici: grint of wothenet is:

Shese Ston $y$

$50555571 n 4$

sury jislanl-gov

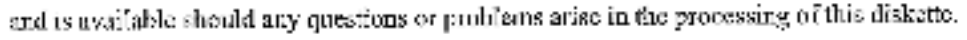

l'age 2 
TRIFID: 87545LSLMISLOSAL

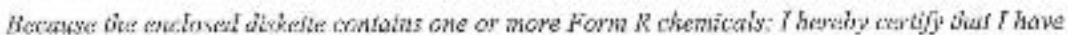

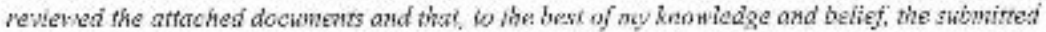

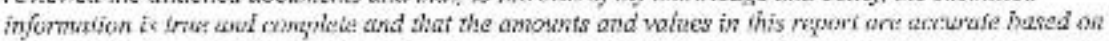

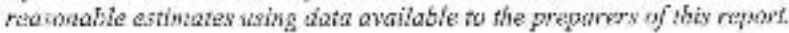

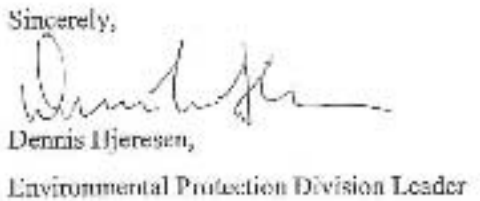

Finclesure

Jisketle

Cy:

G. Tumer, DOF-I.ASO, A316

M. Mallory, PADUPS, A1O2

J. Cantwell, ADFSH\&Q, K491

C. Blackwell, LC-LESII, A187

T. Bonds I.opez, EVV-ERS-DO, J59]

P. Gallagher. LNV-ES, J978

D. Janecky, FNV-ES. J978

S. Story, ENV-ES, Jy78

W. Whetbam, FNVV-FS, I97R

IRM-RMISSO, Al50

EICIRA Project File

ENV-EAQ File 


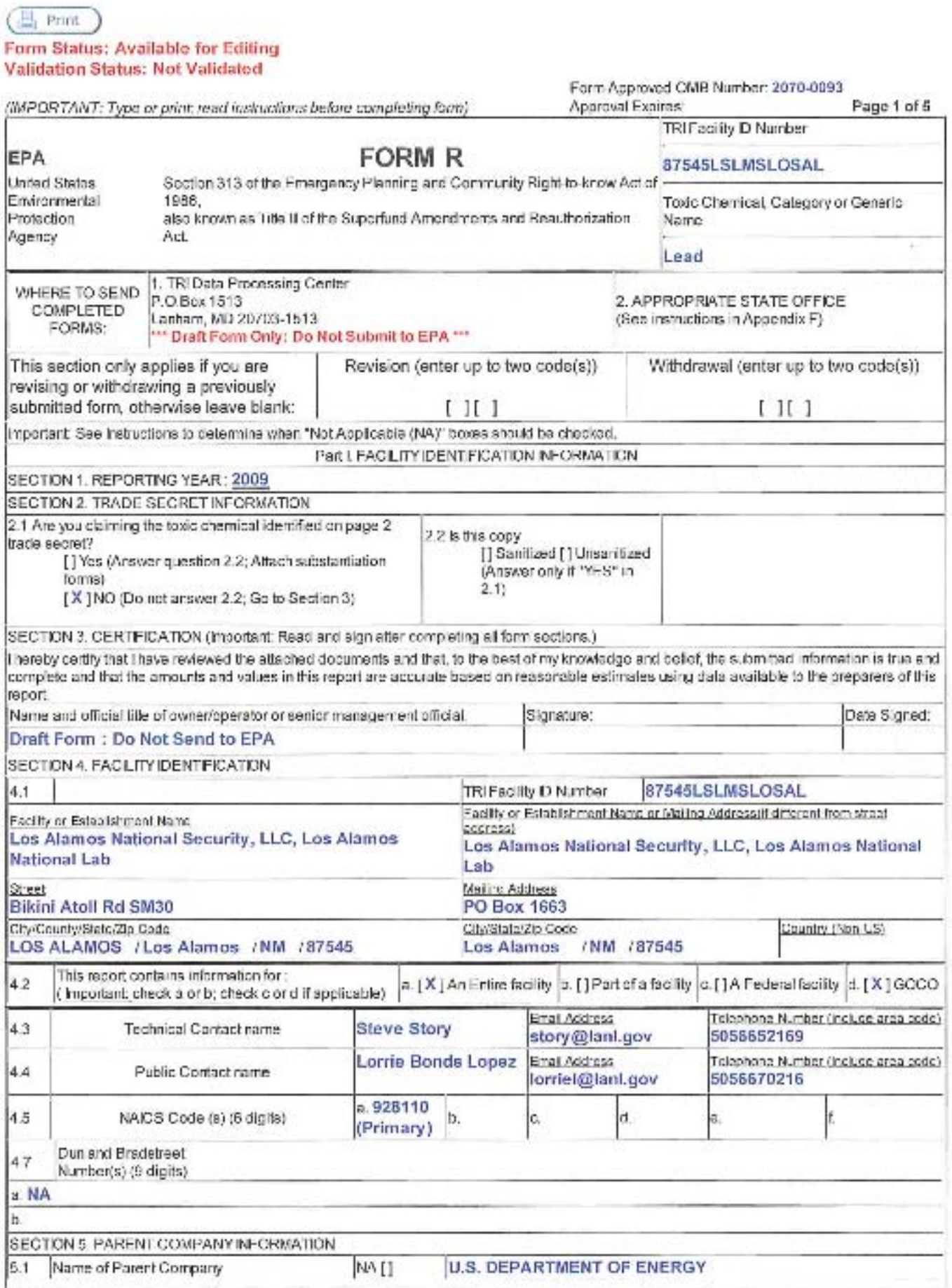




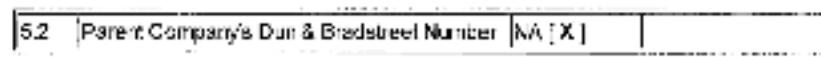

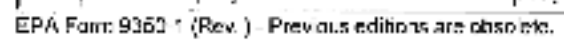

Prithat Isirg IRBatimab 


\begin{tabular}{|c|c|c|c|c|c|}
\hline \multicolumn{6}{|r|}{ Page 2 of 5} \\
\hline & & & & \multicolumn{2}{|l|}{ TrIFecirly D Nunbea } \\
\hline \multirow{2}{*}{\multicolumn{4}{|c|}{$\begin{array}{c}\text { EPA FORM R } \\
\text { PART II. CHEMICAL - SPECIFIC INFORMATION }\end{array}$}} & \multicolumn{2}{|l|}{ B7545LSLMSLOSAL } \\
\hline & & & & \multicolumn{2}{|c|}{ Imo Charrical Catsgory or Genarle Name } \\
\hline & & & & \multicolumn{2}{|c|}{ Lead } \\
\hline \multicolumn{2}{|c|}{ SECTON : TOXOC CHERALAL DENTIY } & \multicolumn{4}{|c|}{ 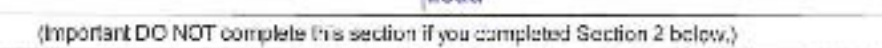 } \\
\hline \multirow{2}{*}{1.1} & \multicolumn{5}{|c|}{ 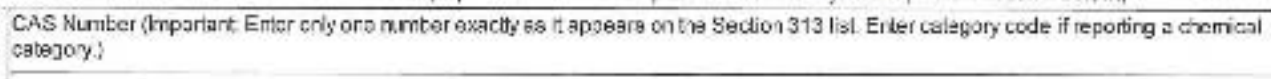 } \\
\hline & \multicolumn{5}{|l|}{7435921} \\
\hline \multirow{2}{*}{1.2} & \multicolumn{5}{|c|}{ 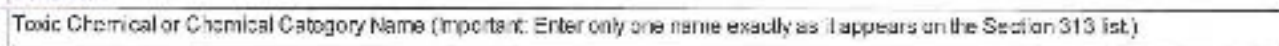 } \\
\hline & \multicolumn{5}{|l|}{ Lead } \\
\hline \multirow{2}{*}{13} & \multicolumn{5}{|c|}{ 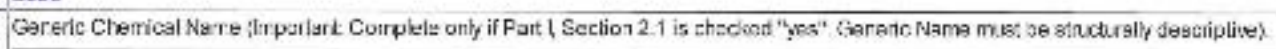 } \\
\hline & \multicolumn{5}{|l|}{ NA } \\
\hline \multicolumn{6}{|c|}{ 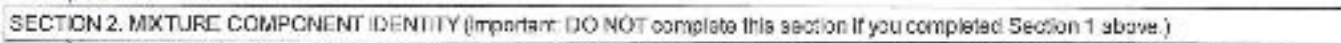 } \\
\hline \multirow{2}{*}{2.1} & \multicolumn{5}{|c|}{ 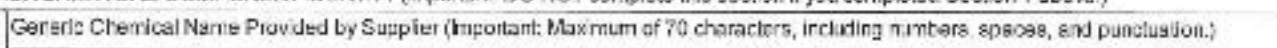 } \\
\hline & \multicolumn{5}{|l|}{ NA } \\
\hline \multicolumn{6}{|c|}{ 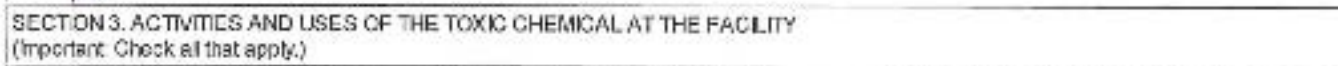 } \\
\hline 3.1 & Mandacture tre 10xdc chemics.: & 3.2 Pruczess & litu soxe civernical: & 3.3 Otharvise 150 tha & toxic chemica: \\
\hline \multicolumn{6}{|c|}{ 3. [] Proc joa b. $[1] \mathrm{mpor}$} \\
\hline \multicolumn{2}{|c|}{ 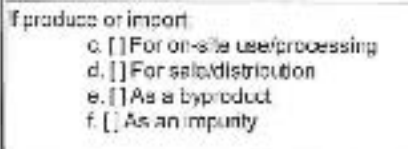 } & \multicolumn{2}{|c|}{ 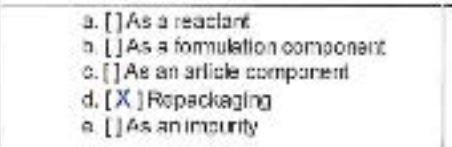 } & \multicolumn{2}{|c|}{ 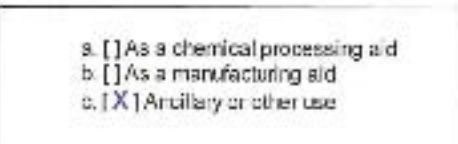 } \\
\hline \multicolumn{6}{|c|}{ SECTON 4. MAXXMUMA AWOUNT OF THE TOXK CHEINCAL ONSITE AT ANYTME DUTJMG THE CALENDAR YEAR } \\
\hline \multicolumn{6}{|c|}{ 4:1 [05 ](Erler tws-digit code forn irstrustian package.) } \\
\hline \multicolumn{6}{|c|}{ SECTION S CUANTITY OF THE TOXIC CHEMCALL ENTERING EACH ENVIRONWENTAL MED UW ONSTE } \\
\hline & & & 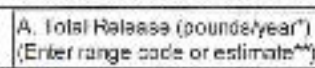 & \begin{tabular}{l|l}
7 & B. Basis of Estimate \\
:nmar nndn!
\end{tabular} & c. $5 / 2$ From Sloctrrasitet \\
\hline 5.1 & $\begin{array}{l}\text { Fuyilive or nan poirt } \\
\text { giremisaiona. }\end{array}$ & NA[] & 4.9 & c & \\
\hline 5.2 & $\begin{array}{l}\text { Stack or poirt } \\
\text { gir ennissisrs }\end{array}$ & NA [1 & 0.52 & E1 & \\
\hline 5.3 & \multicolumn{2}{|l|}{ 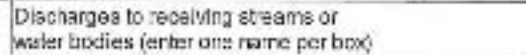 } & & & \\
\hline \multicolumn{3}{|c|}{ Siream or ktater Borty Nams } & & & \\
\hline 5.3 .1 & MORTANDAD TRIBUTARY TC & RIO GRANDE & 0.065 & M2 & $0 \%$ \\
\hline
\end{tabular}




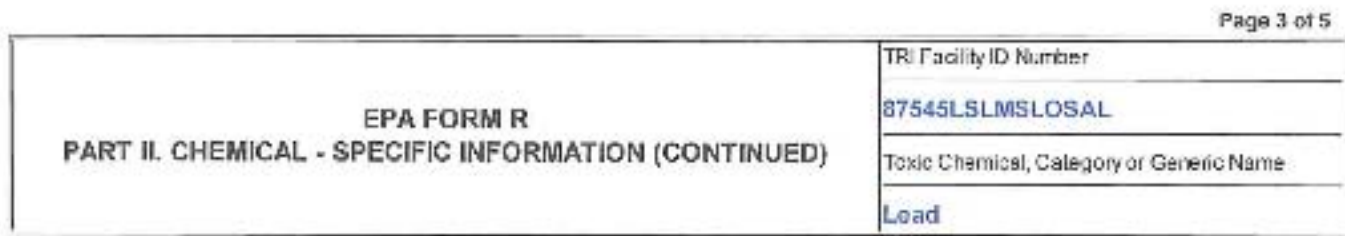

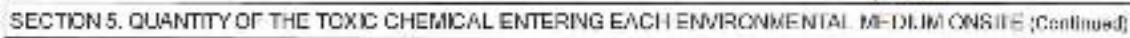

\begin{tabular}{|c|c|c|c|c|}
\hline \multicolumn{2}{|r|}{+} & \multirow{2}{*}[\begin{array}{l}{\text{NA}}\\
{[X]}\end{array}]{} & 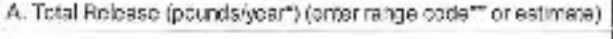 & \multirow{2}{*}{ B. Basis cr Eatimate ;enter coce) } \\
\hline 3.4 .1 & $\begin{array}{l}\text { Undern ound linection onsile } \\
\text { in } G \text { ass lavels. }\end{array}$ & & & \\
\hline 5.42 & $\begin{array}{l}\text { Underg cund lijectien onsil= } \\
\text { to Class +V wels }\end{array}$ & {$[\mathrm{X}]$} & & \\
\hline 5.5 & Dispose to land onsits & & & \\
\hline $5.5 .1 \hat{5}$ & HClRA subtita C landila & {$[\mathrm{X}]$} & & \\
\hline 5.5.1.8 & Other bantalk & {$[x]$} & & \\
\hline 5.5 .2 & $\begin{array}{l}\text { Lant beatmentiospicstion } \\
\text { farrirg }\end{array}$ & {$[\mathrm{X}]$} & & \\
\hline $5.53 \mathrm{~A}$ & $\begin{array}{l}\text { RCRA Suttits } \mathrm{C} \\
\text { Gurfecs Impouncments }\end{array}$ & {$[x]$} & & \\
\hline $6.5 ; \mathrm{H}$ & U:ar sutace impourdnemis & $\mathrm{X}_{1}$ & & \\
\hline 5.5 .4 & Oener dispasal & 115 & 5000.5 & M2 \\
\hline \multicolumn{5}{|c|}{ SHCTKUN 6. TRANSFERS OF THE TOXIC CHEMCAL IV VWSTES TO OTT STI LOCATONS } \\
\hline \multicolumn{5}{|c|}{ 6.1 DISCHARGES TO PLBLCLY OWNED TREATTIENT WOROSS (POTVUS] } \\
\hline \multicolumn{5}{|c|}{ 6.1.2. Total Quarlity Trane'er ed to POTWe end Bgels of Eefimuta } \\
\hline \multirow{2}{*}{\multicolumn{2}{|c|}{ 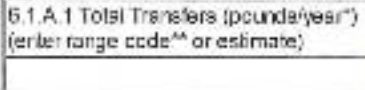 }} & & $8.1 . \mathrm{A}^{2}$ & $\begin{array}{l}2 \text { Basis of Estimate } \\
\text { (erter code) }\end{array}$ \\
\hline & & NA & & \\
\hline
\end{tabular}




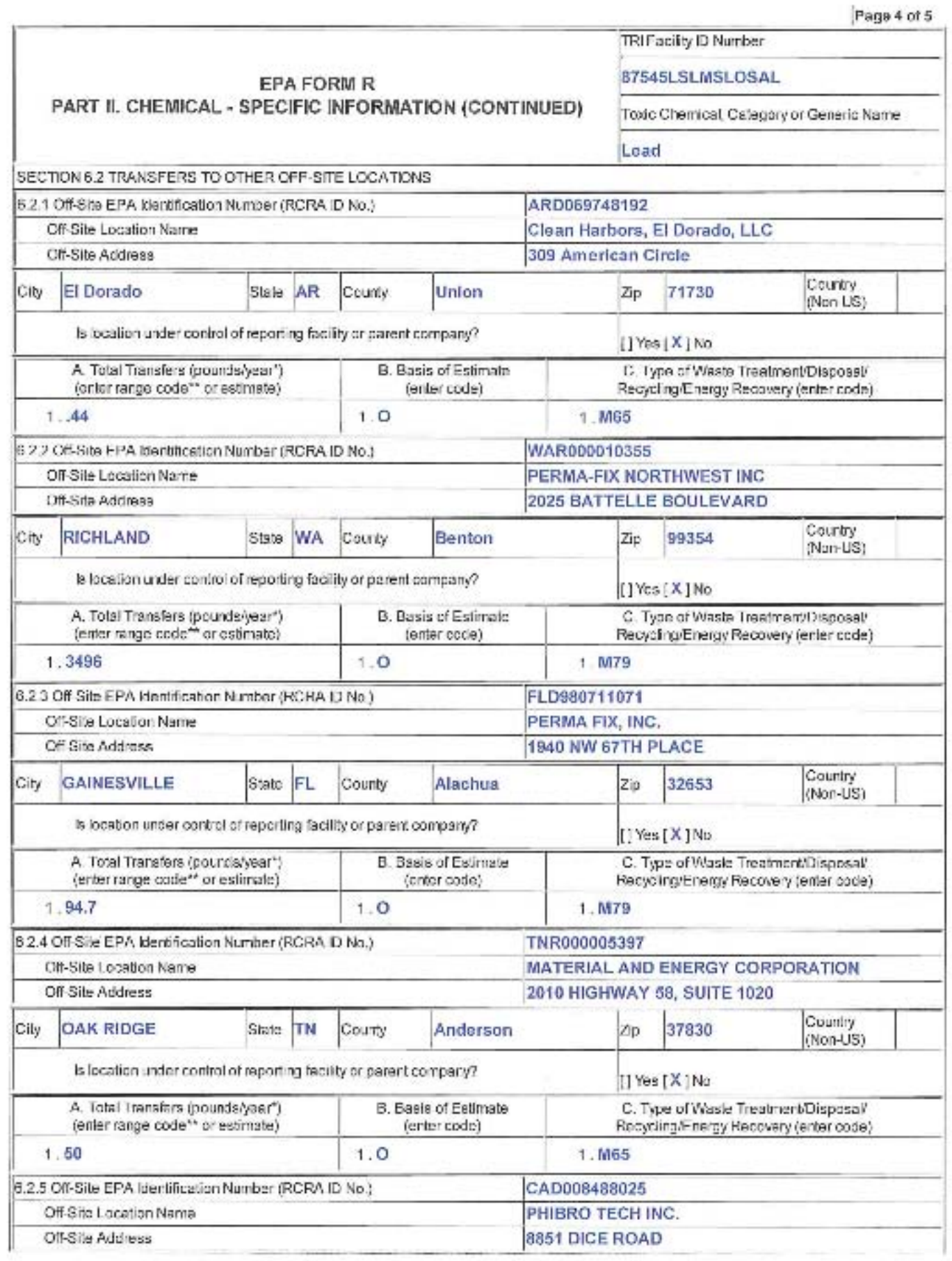




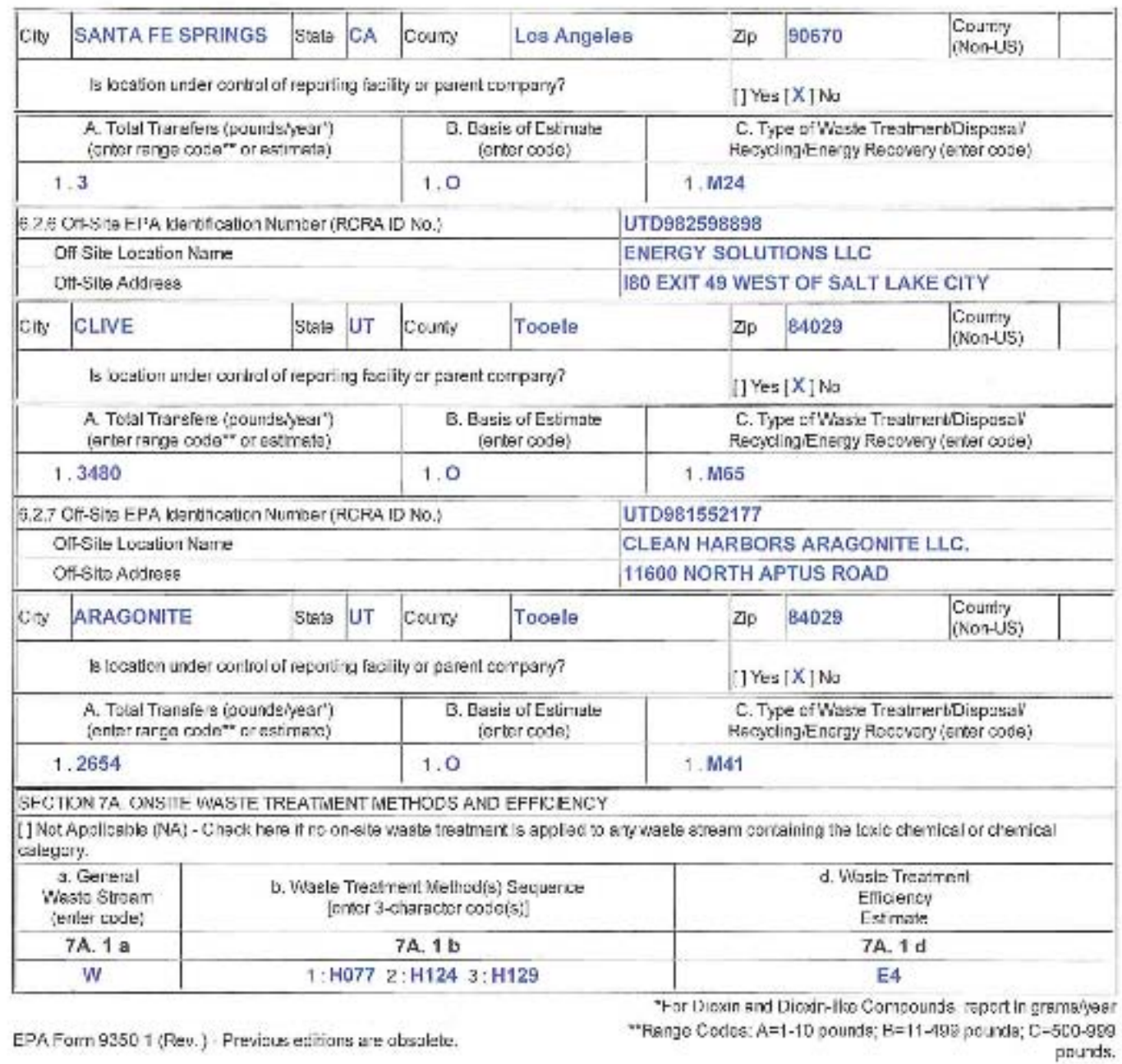




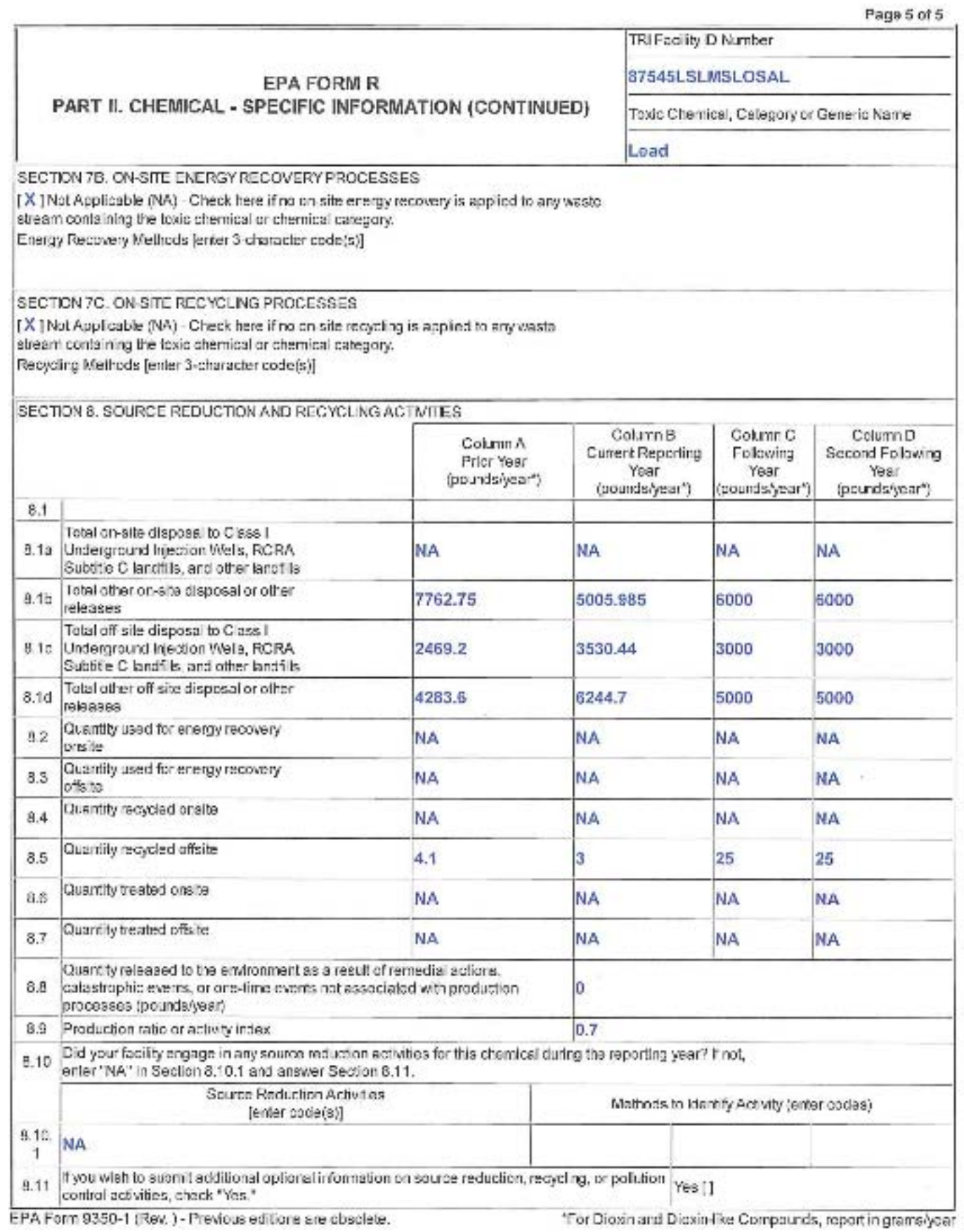




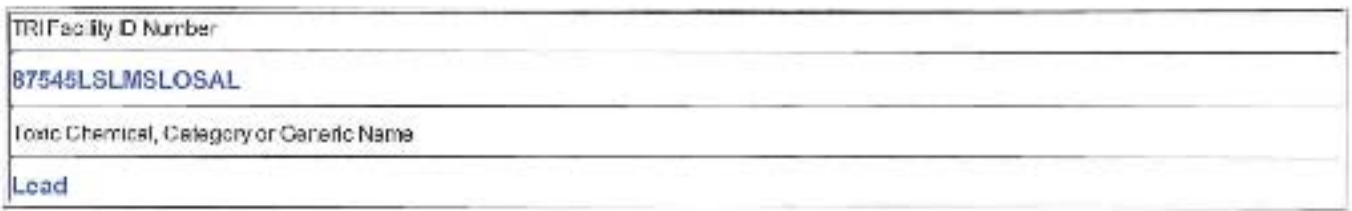

Anditional sptional information on source reduction, recycling, or pollution control activitieg. 
This report has been reproduced directly from the best available copy. It is available electronically on the Web (http://www.doe.gov/bridge).

Copies are available for sale to U.S. Department of Energy employees and contractors from:

Office of Scientific and Technical Information

P.O. Box 62

Oak Ridge, TN 37831

(865) 576-8401

Copies are available for sale to the public from: National Technical Information Service

U.S. Department of Commerce

5285 Port Royal Road

Springfield, VA 22161

(800) 553-6847 
- Los Alamos NATIONAL LABORATORY

EST.1943 